\title{
De arbeidsmarktperspectieven voor Maastrichtse psychologen : een vooronderzoek
}

Citation for published version (APA):

Borghans, L., \& Wiendels, M. R. (1993). De arbeidsmarktperspectieven voor Maastrichtse psychologen : een vooronderzoek. Researchcentrum voor Onderwijs en Arbeidsmarkt, Faculteit der Economische Wetenschappen. ROA Reports No. 8 https://doi.org/10.26481/umarep.1993008

Document status and date:

Published: 01/01/1993

DOI:

10.26481/umarep.1993008

Document Version:

Publisher's PDF, also known as Version of record

\section{Please check the document version of this publication:}

- A submitted manuscript is the version of the article upon submission and before peer-review. There can be important differences between the submitted version and the official published version of record.

People interested in the research are advised to contact the author for the final version of the publication, or visit the DOI to the publisher's website.

- The final author version and the galley proof are versions of the publication after peer review.

- The final published version features the final layout of the paper including the volume, issue and page numbers.

Link to publication

\footnotetext{
General rights rights.

- You may freely distribute the URL identifying the publication in the public portal. please follow below link for the End User Agreement:

www.umlib.nl/taverne-license

Take down policy

If you believe that this document breaches copyright please contact us at:

repository@maastrichtuniversity.nl

providing details and we will investigate your claim.
}

Copyright and moral rights for the publications made accessible in the public portal are retained by the authors and/or other copyright owners and it is a condition of accessing publications that users recognise and abide by the legal requirements associated with these

- Users may download and print one copy of any publication from the public portal for the purpose of private study or research.

- You may not further distribute the material or use it for any profit-making activity or commercial gain

If the publication is distributed under the terms of Article $25 \mathrm{fa}$ of the Dutch Copyright Act, indicated by the "Taverne" license above, 
DE ARBEIDSMARKTPERSPECTIEVEN VOOR MAASTRICHTSE PSYCHOLOGEN

- een vooronderzoek -

ROA-R-1993/8

L. Borghans

M.R. Wiendels

RESEARCHCENTRUM VOOR ONDERWIJS EN ARBEIDSMARKT

Faculteit der Economische Wetenschappen

Rijksuniversiteit Limburg

Maastricht, juli 1993 
CIP-GEGEVENS KONINKLIJKE BIBLIOTHEEK, DEN HAAG

Borghans, L.

De arbeidsmarktperspectieven voor Maastrichtse psychologen: een vooronderzoek / L. Borghans, M.R. Wiendels. - Maastricht: Researchcentrum voor Onderwijs en Arbeidsmarkt, Faculteit der Economische Wetenschappen, Rijksuniversiteit Limburg. - (ROA-R-1993/8)

Met lit. opg.

ISBN 90-5321-109-8 geb.

Trefw.: arbeidsmarkt; psychologen. 


\section{INHOUDSOPGAVE}

Bladzijde

1. INLEIDING 1

1.1. Achtergrond van het onderzoek 1

$\begin{array}{ll}\text { 1.2. Uitgangspunten van het onderzoek } & 1\end{array}$

1.3. Opzet van deze studie 4

2. ONDERZOEK NAAR DE ARBEIDSMARKT VAN PSYCHOLOGEN 6

2.1. Inleiding 6

2.2. Afstudeerrichtingen $\quad 7$

2.3. Bestemming van psychologen 9

$\begin{array}{ll}\text { 2.4. Werkloosheid } & 11\end{array}$

3. HET AANBOD VAN PSYCHOLOGEN 13

3.1. Inleiding 13

$\begin{array}{ll}\text { 3.2. Het kwantitatief aanbod } & 13\end{array}$

$\begin{array}{ll}\text { 3.3. Herkomst van het aanbod } & 17\end{array}$

4. ALGEMENE ONTWIKKELINGEN AAN DE VRAAGKANT 21

5. ONTWIKKELINGEN BINNEN DE BEROEPSGROEP 24

5.1. Inleiding 24

5.2. Het NIP-ledenbestand 25

6. PSYCHOLOGIE IN DE VERENIGDE STATEN 32

6.1. Inleiding 32

6.2. Bureau of Labor Statistics 32

6.3. American Psychological Association $\quad 34$

7. MOGELIJKHEDEN VOOR ARBEIDSMARKTPROGNOSES 40

$\begin{array}{ll}\text { LITERATUUR } & 44\end{array}$ 



\section{INLEIDING}

\subsection{Achtergrond van het onderzoek}

In het rapport 'Psychologie in Maastricht' zet de Commissie Psychologie (1993) van de Rijksuniversiteit Limburg haar plannen uiteen om te komen tot een studierichting psychologie aan deze universiteit. In tegenstelling tot de opzet van de reeds bestaande psychologieopleidingen, zou het hier niet moeten gaan om een algemeen opgezette studie, maar zal het onderwijsprogramma toegespitst worden op de vakgebieden biopsychologie en cognitieve psychologie. In de motivering om te komen tot deze studierichting wijst de commissie op de reeds aanwezige expertise op deze terreinen aan de Rijksuniversiteit Limburg, het specifieke karakter van het onderwijs (het Probleem Gestuurd Onderwijs) aan deze universiteit en het toenemend belang van biopsychologie en cognitieve psychologie in het (internationale) wetenschappelijk onderzoek.

Naast deze punten is ook het te verwachten arbeidsmarktperspectief voor de afgestudeerde Maastrichtse psychologen een punt van aandacht voor de commissie. Zij stelt echter dat op basis van het reeds beschikbare onderzoek over de arbeidsmarktperspectieven in kwantitatief opzicht slechts tentatieve uitspraken gedaan kunnen worden. Om meer zicht te krijgen op de te verwachten arbeidsmarktsituatie voor de afgestudeerde bio- en cognitieve psychologen heeft de Commissie Psychologie aan het Researchcentrum voor Onderwijs en Arbeidsmarkt (ROA) gevraagd om een onderzoek in te stellen naar de arbeidsmarktperspectieven voor de Maastrichtse psychologen. Omdat nog onduidelijk was welke mogelijkheden er zijn om te komen tot verantwoorde prognoses c.q. inzichten in de toekomstige arbeidsmarktsituatie, is besloten allereerst een vooronderzoek uit te voeren, waarin deze mogelijkheden geïnventariseerd worden. In dit rapport wordt verslag gedaan van dit vooronderzoek. Daarbij wordt nagegaan welke informatiebronnen beschikbaar zijn voor het maken van prognoses van de arbeidsmarktsituatie van bio- en cognitieve psychologen en welke prognoses op basis van deze data gemaakt kunnen worden.

\subsection{Uitgangspunten van het onderzoek}

De algemene arbeidsmarktsituatie voor sociale wetenschappers en de verwachte ontwikkelingen daarin lijken op het eerste gezicht niet erg rooskleurig. ROA (1992) omschrijft het arbeidsmarktperspectief voor de periode tot 1994 als slecht. Dit geldt echter voor een groot aantal academische studierichtingen. Vergeleken met de andere studierichtingen nemen de sociale wetenschappen een middenpositie in. De werkloosheid in 1991 onder de totale groep WO Sociaal-Cultureel was $6 \%$, terwijl de werkloosheid onder de recent afgestudeerden $9 \%$ was (zie ROA, 1992b). Met dit werkloosheidscijfer voor afgestudeerden bevindt de groep WO Sociaal-Cultureel zich tussen aan de ene kant de techische en economische wetenschappen (respectievelijk $4 \%$ en $3 \%$ werkloosheid) en aan de andere kant de humaniora, theologie, agrarische wetenschappen en wiskunde en natuurwetenschappen (met 11 tot $13 \%$ werkloosheid). Voor de studierichting psychologie schatten Dijkstra en Van den Donk (1988) 
echter een werkloosheid in 1987, die veel hoger ligt dan de gemiddelde werkloosheid onder sociale wetenschappers. Zij berekenen een werkloosheidspercentage van $13,6 \%$ voor de psychologen, terwijl de werkloosheid bij sociologie op $8,5 \%$ wordt geraamd. Volgens deze schattingen kent de psychologie een werkloosheidscijfer dat vergelijkbaar is met veel talenstudies en bevindt de studie zich derhalve in een relatief zwakke positie ten opzichte van andere studierichtingen. Alleen studierichtingen zoals filosofie, geschiedenis en culturele antropologie hebben vanuit dit gezichtspunt een nog zwakkere arbeidsmarktpositie.

Afgezien van het feit dat bovenstaande cijfers slechts een vage indicatie geven voor de perspectieven van een studie bio- en cognitieve psychologie en recentere cijfers die inzicht kunnen geven in de arbeidsmarktpositie van psychologen niet onmiddellijk voorhanden zijn, is het ook van belang deze onderlinge rangschikking van studierichtingen op grond van hun arbeidsmarktpositie zorgvuldig te interpreteren. De aansluiting tussen onderwijs en arbeidsmarkt is optimaal als het onderwijssysteem gegeven de beschikbare middelen zo goed mogelijk aan de vraag naar een bepaalde scholing voldoet. De mate waarin hieraan kan worden voldaan is naast de beschikbare financiering - vooral afhankelijk van de capaciteiten van de studenten, terwijl de vraag voortkomt uit individuele preferenties, maatschappelijk belang en de arbeidsmarktvraag naar personen met een bepaalde opleiding. Zonder het belang van academische opleidingen voor de persoonlijke en maatschappelijke ontwikkeling uit het oog te willen verliezen, gaat in deze studie naar de arbeidsmarktperspectieven van de afgestudeerden de aandacht vanzelfsprekend primair uit naar de arbeidsmarktvraag naar personen met bepaalde capaciteiten en een bepaalde opleiding.

Om een goede aansluiting van het onderwijs op de arbeidsmarkt te bewerkstelligen dient derhalve gegeven het beschikbaar potentieel aan studenten een zo hoog mogelijk arbeidsmarktrendement behaald te worden. Voor een nieuw op te richten studierichting, zoals psychologie in Maastricht, kan een goede aansluiting tussen onderwijs en arbeidsmarkt vanuit twee invalshoeken benaderd worden, te weten:

- de aansluiting op de vraag op de arbeidsmarkt;

- de toegevoegde waarde van de opleiding.

\section{Aans/uiting met de vraag}

Ten eerste kan een studierichting inspelen op lacunes in het bestaande aanbod. Er kan vraag ontstaan zijn naar academici met een bepaalde specialisatie, waaraan het reguliere onderwijs niet of in onvoldoende mate weet te beantwoorden. Dit is de invalshoek van de 'manpower requirement benadering'. Er wordt een confrontatie gemaakt van de toekomstige vraag en het toekomstig aanbod voor een bepaald type opleiding. Als het aanbod tekort schiet ten opzichte van de vraag lijkt er ruimte te zijn voor extra aanbod. Oorspronkelijk (in de jaren zestig) werden dit soort exercities vooral verricht vanuit een planningsgedachte. Hierdoor werd de aanpak zeer vraagbepaald. Als er aan werkgeverszijde vraag is naar bepaalde opleidingen zou het onderwijs hieraan aangepast moeten worden. Tegenwoordig wordt het vraagbegrip echter relatiever opgevat (zie Van Eijs, 1993). Er kan een relatief tekort aan bepaalde specialisaties zijn als zowel 
de student als de toekomstige werkgever baat hebben bij de keuze voor deze nieuwe richting, maar door gebrekkige informatie of door capaciteitsproblemen niet aan deze tweezijdige vraag kan worden voldaan. $\mathrm{Er}$ is in deze visie dus een tekort aan personen met een bepaalde opleiding, als er in de toekomst banen zijn die studenten graag zouden willen vervullen, maar waarvan ze óf niet weten dat deze mogelijkheden er zijn, of de mogelijkheid niet krijgen zich van deze functies adequaat te kwalificeren. Deze nieuwe benadering richt zich dan ook niet meer zozeer op planning, maar op informatieverstrekking. Studenten dienen informatie te krijgen over de toekomstperspectieven van bepaalde opleidingen, zodat ze een goede afweging kunnen maken tussen de diverse opleidingen. Opleidingsinstituten dienen over informatie te beschikken met betrekkking tot de werkterreinen waarvoor dergelijke gunstige arbeidsmarktperspectieven bestaan.

Voor nieuwkomers op de arbeidsmarkt bestaat de relevante vraag naar arbeid uit twee componenten. Omdat zij immers niet snel de reeds werkzame personen uit hun baan zullen verdringen, zijn zij in de eerste plaats afhankelijk van een uitbreiding van het aantal banen (de 'uitbreidingsvraag'). In de tweede plaats kunnen zij ook de functie krijgen van iemand die ophoudt met werken ('vervangingsvraag'). Voor een prognose van de arbeidsmarkt van psychologen zijn beide vraagcomponenten van belang. Verder dient de vraag vergeleken te worden met het relevante nieuwe aanbod van afstudeerders.

Voor de bestudering van de toekomstige arbeidsmarktpositie van een nieuwe opleiding psychologie leidt dit tot vragen als: Is er voldoende vraag te constateren lof in de nabije toekomst te verwachten) in de beroepen waar mensen werken met een opleiding die vergelijkbaar is met de beoogde opleiding bio- en cognitieve psychologie in Maastricht? Of is er een dergelijke vraag in beroepen waar mensen met deze nieuwe opleiding zeer geschikt voor zouden zijn?

\section{Toegevoegde waarde van de opleiding}

Een tweede invalshoek voor het beoordelen van de arbeidsmarktaspecten van een nieuwe studierichting vertrekt niet vanuit de vraagkant, maar vanuit de aanbodkant. Er zijn altijd studierichtingen waarvoor de arbeidsmarktperspectieven beter zijn dan voor andere. Dit succes kan echter niet geheel toegeschreven worden aan deze studierichtingen, aangezien de groep studenten die instroomt in het academisch onderwijs heterogeen is, en bepaalde studierichtingen studenten rekruteren die a priori reeds betere arbeidsmarktperspectieven hebben dan anderen. Het arbeidsmarktsucces van een opleiding wordt gevormd door de som van de persoonlijke kwaliteiten aan het begin van de studie en de toegevoegde waarde van de studie. Voorzover een studierichting alleen de betere studenten selecteert is er slechts sprake van screening. De produktiviteit van de student kan dan nauwelijks aan de opleiding toeberekend worden. De toegevoegde waarde van de opleiding wordt in feite bepaald door de toename van de produktiviteit die door de opleiding bewerkstelligd wordt, dat wil zeggen door de vergroting van het human capital (zie Blaug, 1987). 
Vanuit dit perspectief kan een nieuwe opleiding psychologie het arbeidsmarktrendement verbeteren als men in staat is om, vergeleken met soortgelijke studierichtingen, een vergelijkbare groep studenten een beter arbeidsmarktperspectief te bieden. Dit leidt, met betrekking tot psychologie in Maastricht tot vragen als: Welk type student zal waarschijnlijk instromen in de nieuwe studierichting? Geven de beoogde typerende kenmerken van de nieuwe studierichting - de $\beta$-invalshoek en het PGO-systeem - vooruitzicht op een verbetering van de kansen op de arbeidsmarkt voor de betrokkenen?

In tegenstelling tot het eerste, vraagbepaalde, perspectief, ligt hierbij het accent meer op de (sterke en zwakke) kenmerken van het aanbod. Bij de eerste invalhoek wordt gekeken naar de ontwikkeling van de vraag naar functies die typisch zijn voor de bedoelde studierichting, terwijl in de tweede invalshoek bekeken wordt hoe de arbeidsmarktkansen tussen de verschillende verwante studierichtingen zich verhouden. Hierbij is niet alleen het primair beoogde beroepssegment van belang, maar kan het in principe gaan om de arbeidsmarktperspectieven over de gehele arbeidsmarkt. In de analyse moeten dan ook degenen betrokken worden die niet in typische psychologieberoepen terechtkomen, maar die elders op de arbeidsmarkt werk zullen vinden, of werkloos zullen blijven.

\subsection{Opzet van deze studie}

De hierboven beschreven analyse van de aansluitingsproblematiek dient als uitgangspunt voor het verkennend onderzoek waarvan in dit rapport verslag wordt gedaan. Doel van dit vooronderzoek is te inventariseren in hoeverre het mogelijk is voorspellingen te maken voor de toekomstige arbeidsmarktpositie van studenten die de opleiding bio- en cognitieve psychologie gevolgd hebben. Omdat bij het starten van een nieuwe studierichting de eerste afgestudeerden pas over minimaal vier jaar op de arbeidsmarkt zullen komen dient zo'n voorspelling een termijn van minimaal vijf jaar te beslaan. Naast echte voorspellingen van de toekomstige arbeidsmarktpositie voor de Maastrichtse psychologen zal echter ook gekeken worden naar de mogelijkheid tot het uitvoeren van analyses die inzicht geven in de recente ontwikkelingen in de arbeidsmarktsituatie van bio- en cognitieve psychologen. Zulke analyses kunnen trends in de markt voor psychologen aan het licht brengen zonder meteen als een precieze voorspelling voor een bepaald jaar te fungeren.

Voordat wordt ingegaan op de beschikbare databronnen en de mogelijkheden die deze bieden voor het maken van verdere analyses wordt in hoofdstuk 2 eerst een overzicht gegeven van het reeds bestaande onderzoek naar de arbeidsmarkt van psychologen. Veel van dit onderzoek is echter verouderd en doorgaans biedt het onvoldoende detail om over de markt voor bio- en cognitieve psychologen iets te kunnen zeggen. Wel geven de beschikbare onderzoekresultaten, door ze in onderling verband te plaatsen, enig inzicht in de arbeidsmarktontwikkelingen binnen de psychologie.

In hoofdstuk 3 wordt aandacht besteed aan het het aanbod van studenten. De voornaamste bron hierbij zijn de referentie- en verdeelramingen van het Ministerie van Onderwijs en 
Wetenschappen die voorspellingen geven van de in- en uitstroom van studenten in de psychologie. Verder is het - gezien vanuit het hierboven beschreven kader - ook relevant uit welke groepen de studierichting psychologie haar studenten verwerft. Ook aan dit onderwerp wordt in dit hoofdstuk aandacht besteed.

Voor een bepaling van de arbeidsmarktpositie van psychologen dient de instroom van studenten vergeleken te worden met de ontwikkelingen aan de vraagkant, en voor een bepaling van de toegevoegde waarde van een studierichting moet een vergelijking gemaakt worden met studierichtingen die in eenzelfde segment van de arbeidsmarkt zitten. In hoofdstuk 4 wordt dit bekeken vanuit de algemene arbeidsmarktsituatie van afgestudeerde psychologen, dus ook degenen die buiten de psychologie komen te werken. Hiervoor is informatie vereist over de Nederlandse arbeidsmarkt als geheel. De data-bestanden die hiervoor het meest geëigend zijn, zijn de Arbeidskrachtentelling (AKT) en de Enquête Beroepsbevolking (EBB). Besproken wordt in hoeverre deze databestanden bruikbaar zijn voor een dergelijke analyse en in hoeverre een koppeling te maken is met de voorspellingen die het ROA momenteel opstelt voor de arbeidsmarkt naar opleiding en beroep in 1998.

In hoofdstuk 4 wordt het accent verlegd van de vergelijking van de algemene arbeidsmarktsituatie van studenten bio- en cognitieve psychologie met richtingen die voor deze studenten als alternatief fungeren, naar de ontwikkelingen in de vraag. Hierbij is met name de vraag naar psychologen in typische psychologieberoepen relevant. Om inzicht te krijgen in deze ontwikkeling kan gebruik gemaakt worden van ledenbestanden van verenigingen van psychologen. Het enige bestand dat in aanmerking blijkt te komen voor een dergelijke analyse is het ledenbestand van het Nederlands Instituut voor Psychologen. Er worden enkele voorlopige cijfers op basis van dit bestand gepresenteerd en er wordt besproken hoe dit cijfermateriaal gebruikt kan worden voor het opstellen van voorspellingen.

In hoofdstuk 5 komt de situatie in de Verenigde Staten aan bod. De gedachte hierbij is dat de arbeidsmarktontwikkelingen binnen de psychologie in de Verenigde Staten een indicatie kunnen geven van de ontwikkelingen die ook in Nederland te verwachten zijn, onder de vooronderstelling dat de Nederlandse situatie de ontwikkelingen in de Verenigde Staten na verloop van tijd zal volgen.

In hoofdstuk 6, tenslotte, worden de besproken mogelijkheden voor het maken van arbeidsmarktvoorspellingen op een rij gezet en worden aanbevelingen gedaan voor de wijze waarop een hoofdonderzoek naar de arbeidsmarktperspectieven van bio- en cognitieve psychologen vorm kan krijgen. 



\section{ONDERZOEK NAAR DE ARBEIDSMARKT VAN PSYCHOLOGEN}

\subsection{Inleiding}

De arbeidsmarkt voor psychologen is de laatste jaren regelmatig onderzocht. Deze aandacht komt hoogstwaarschijnlijk voort uit de zorgelijke positie die afgestudeerde psychologen innemen op de arbeidsmarkt. Om twee redenen is het interessant om stil te staan bij deze bestaande literatuur. Ten eerste verschaft het eerder verrichte onderzoek informatie over de mogelijke data-bestanden waarop een nieuw onderzoek naar psychologen kan worden gebaseerd en ten tweede kunnen de resultaten van deze onderzoeken te zamen inzicht geven in de ontwikkelingen die de psychologenmarkt hebben plaatsgevonden.

Daarentegen heeft de bestaande literatuur ook een tweetal tekortkomingen. Ten eerste is het meeste onderzoek tamelijk verouderd, zodat het in ieder geval niet direct bruikbaar is om inzicht te krijgen in de huidige en toekomstige ontwikkelingen. Hoogstens kan het deze in een historisch perspectief plaatsen. Ten tweede is het doelgebied van de Maastrichtse psychologiestudie, de bio- en cognitieve psychologie, binnen de bestaande literatuur slechts een randgebied. Slechts zo nu en dan wordt bijvoorbeeld de verwante afstudeerrichting functieleer expliciet vermeld in het onderzoek, maar meestal vallen de afstudeerrichtingen die verwant zijn aan de Maastrichtse studierichting binnen de categorie 'overige'. De meeste aandacht in het tot op heden verrichte onderzoek gaat uit naar de klinisch psychologen ${ }^{1}$. Zij vormen dan ook de grootste groep binnen de psychologie. Daarnaast komen ook de richtingen sociale psychologie, ontwikkelingsleer en arbeids- en organisatiepsychologie regelmatig aan bod in de literatuur.

De meeste onderzoeken maken gebruik van ad hoc enquêtes onder afgestudeerde psychologen ${ }^{2}$. Er bestaan in Nederland geen systematische periodieke enquêtes onder afgestudeerde psychologen zoals bijvoorbeeld wel het geval is in de Verenigde Staten ${ }^{3}$. Jonkergouw (1985a, 1985b, 1986) pleit ervoor om in Nederland ook zulke systematische enquêtes op te zetten, maar tot op heden zijn deze niet tot stand gekomen. Mogelijk zal in de toekomst voor het wetenschappelijk onderwijs onderzoek onder afgestudeerden op gang komen dat vergelijkbaar is met de HBO-Monitor (zie Van de Loo, Ramaekers en Van der Velden 1992) of RUBS (zie Wieling, Van de Loo en Van der Velden, 1993). Vooralsnog kennen alleen de Landbouwuniversiteit Wageningen ${ }^{4}$ en de Rijksuniversiteit Limburg $^{5}$ een dergelijk onderzoek onder al hun afgestudeerden. Sinds kort wordt ook bij de Faculteit Sociale Wetenschappen van de Universiteit Utrecht een vergelijkbare enquête gehouden onder alle studierichtingen aan deze

1. Bijvoorbeeld Kerkhof en Engels (1986), Dijkstra en Bannenberg (1986), Schaufeli (1987), Schaufeli en De Vries (1987) en Beekman en Heijke (1990).

2. Krijnen (1975, 1976), Janssen, Derks en Van Giels (1988) en Mensen en Van den Burgh (1989).

3. In hoofdstuk 6 wordt ingegaan op deze surveys van de American Psychological Association (APA).

4. Het uitstroomonderzoek van de Landbouwuniversiteit Wageningen wordt verzorgd door NILI-NPW.

5. De zogenaamde RL-scanner. Zie bijvoorbeeld Ramaekers en Heijke (1993). 
faculteit (zie Kops en Swanborn, 1993). Dit onderzoek is echter nog niet genoeg gevorderd om er zinvolle analyses mee uit te kunnen voeren. Tot op heden is het slechts eenmaal gehouden en bevat het onderzoek alleen informatie over de situatie vier maanden na het afstuderen. Bovendien zijn bij de specifieke afstudeerrichtingen die vergelijkbaar zijn met bio- en cognitieve psychologie de aantallen in het onderzoek betrokken afgestudeerden te klein voor het doen van statistisch zinvolle uitspraken. In totaal bevat het bestand nu 151 psychologen. Zeker als dit onderzoek de komende jaren wordt voortgezet zal het echter interessante informatie opleveren over de arbeidsmarktpositie van de diverse afstudeerrichtingen van psychologen uit Utrecht.

Naast de ad hoc enquêtes zijn er nog twee belangrijke bronnen van informatie die gebruikt kunnen worden voor onderzoek naar de arbeidsmarkt van psychologen. Ten eerste gebruiken Beekman en Heijke (1990) en Holtzer (1984) het ledenbestand van het Nederlands Instituut van Psychologen (NIP). In hoofdstuk 5 wordt ingegaan op de mogelijkheden van dit NIPledenbestand. Daarnaast gebruiken bijvoorbeeld Holtzer (1984) en Schaufeli (1987) en Beekman en Heijke (1990) de werkloosheidsregistratie van de Arbeidsvoorzieningorganisatie.

Dit hoofdstuk over de bestaande literatuur over de arbeidsmarkt voor psychologen is opgesplitst in drie delen. In paragraaf 2.2 wordt ingegaan op de verdeling van studenten over de afstudeerrichtingen. In paragraaf 2.3 wordt aangegeven waar de psychologen terechtkomen op de arbeidsmarkt en in paragraaf 2.4 wordt een overzicht gegeven van de gegevens die beschikbaar zijn met betrekking tot de werkloosheid van psychologen.

\subsection{Afstudeerrichtingen}

Er zijn twee studies waarin een langere tijdreeks gegeven wordt van de aantallen afgestudeerden per afstudeerrichting binnen de psychologie. Krijnen (1976) geeft cijfers tot en met 1972, terwijl Holtzers (1984) gegevens tot en met het studiejaar 1984/85 doorgaan. Recentere cijfers zijn nog niet beschikbaar. Tabel 2.1 bevat de bevindingen van Holtzer per studiejaar, ter vergelijking aangevuld met het totaalcijfer van Krijnen. De afstudeeraantallen van Krijnen zijn afkomstig uit een grote enquête onder psychologen, terwijl Holtzer zijn data verkreeg via de universiteiten.

Figuur 2.1 laat het verloop zien van het aandeel van functieleer in de uitstroom van afgestudeerden psychologie. Van de onderscheiden afstudeerrichtingen is functieleer het meest verwant aan de Maastrichtse psychologiestudie. Per jaar beschouwd wijkt in bijna geen enkel jaar de relatieve uitstroom van functieleer significant af van de gemiddelde uitstroom over de gehele periode. Alleen in de jaren ' 69 tot ' 72 ligt de uitstroom significant boven de gemiddelde uitstroom in de gehele waarnemingsperiode. Ook bij een samenvoeging van opeenvolgende jaren - zodat de beschouwde populaties groter worden - blijkt de uitstroom bij functieleer niet significant af te wijken van de gemiddelde uitstroom over de gehele periode. Ongeveer $5 \%$ van de afgestudeerden is dus gespecialiseerd in functieleer. 
-8-

Tabel 2.1. Afgestudeerde psychologen naar richting

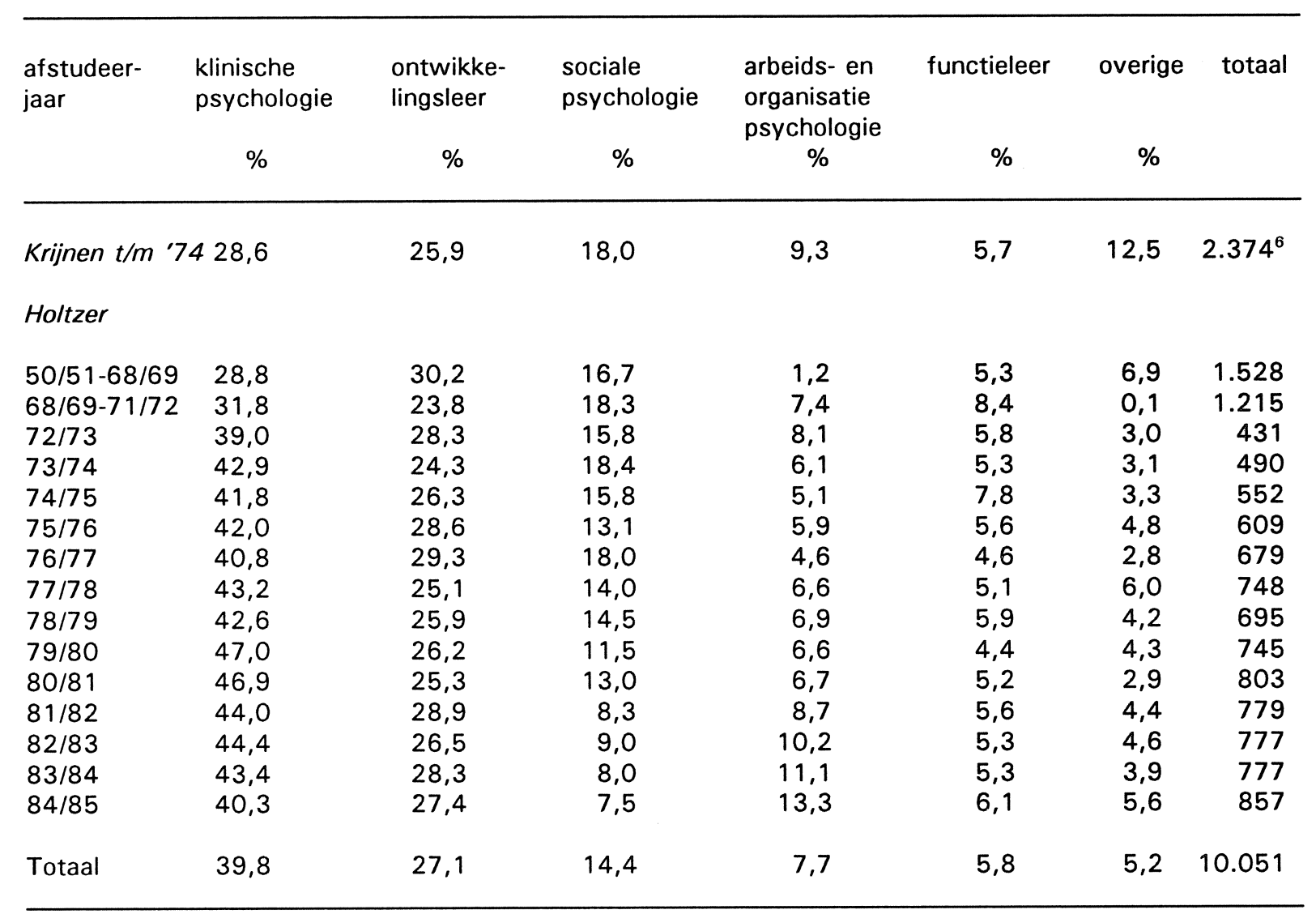

Bron: Holtzer (1984) en Krijnen (1976)

6. Omdat het onderzoek van Krijnen gebaseerd is op een enquête kan dit totaal cijfer kleiner zijn dan het werkelijk aantal afgestudeerden. 
$-9-$

Figuur 2.1. Aandeel van de afstudeerrichting functieleer in de totale uitstroom psychologie met betrouwbaarheidsinterval voor een constante relatieve uitstroom

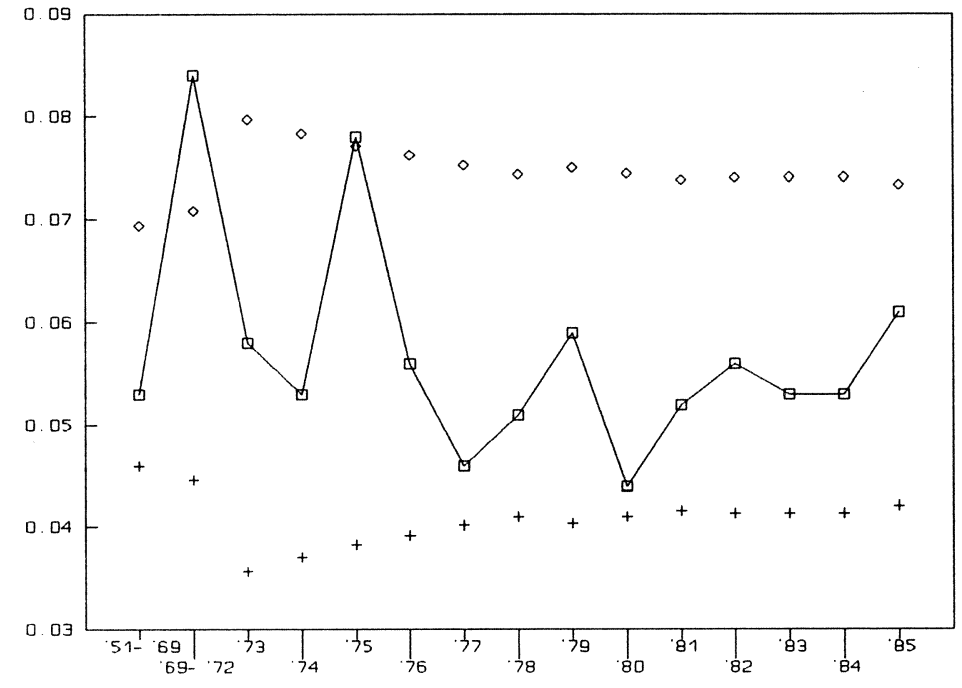

\subsection{Bestemming van psychologen}

In een aantal publikaties wordt aandacht besteed aan de bestemming van afgestudeerde psychologen op de arbeidsmarkt. Deze bestemming kan worden uitgesplitst naar beroep en bedrijfstak. Mensen en Van der Burgh (1989) geven een overzicht van de belangrijkste beroepen van afgestudeerde psychologen op basis van een enquête onder afgestudeerden van het studiejaar 1985-1987. In tabel 2.2 worden deze beroepen afgezet tegen de belangrijkste beroepen bij sociologie.

Tabel 2.2. Verdeling van sociologen en psychologen over de belangrijkste beroepen

sociologen

$\%$ psychologen

$\%$

$\begin{array}{rr}4,2 & 6,7 \\ 4,2 & 4,5 \\ 0,8 & \\ 9,3 & 8,4 \\ & 25,0 \\ 31,9 & 21,8 \\ & 0,6 \\ 5,1 & 0,6 \\ 118 & 180\end{array}$

Bron: Mensen en Van den Burgh (1989) 
De beroepsterreinen bij psychologen blijken redelijk overeen te komen met de beroepsspreiding bij sociologen. Een uitzondering is de grote groep afgestudeerde psychologen die werkzaam als psycholoog. Ongeveer $5 \%$ van de sociologen is beleidsmedewerker, terwijl dit beroep bij de psycholgen bijna niet voorkomt. Bovendien zijn er aanmerkelijk meer sociologen werkzaam als onderzoeker dan psychologen. Ook Krijnen (1976) en Janssen, Derks en Van Giels (1988) geven een beeld van de beroepsterreinen van afgestudeerde psycholgen over beroepen. Janssen vindt dat $60 \%$ van de psychologen in onderwijs $(20 \%)$ en onderzoek $(40 \%)$ werkzaam zijn. Zijn indeling is overigens moeilijk vergelijkbaar met de indeling van Mensen en Van den Burgh. Krijnen hanteert weer een andere beroepenindeling en treft slecht $2 \%$ van de psychologen aan als docent. Verder constateert hij een daling van het aandeel van de experimenteel-psycholoog en de research-psycholoog tussen 1966 en 1975.

Al met al leveren de bestaande cijfers over de verdeling over beroepen een verwarde indruk op. Een groot deel van deze onduidelijkheid wordt veroorzaakt doordat niet erg helder is welke beroepenclassificatie gehanteerd wordt, en deze classificaties ook niet op elkaar lijken aan te sluiten. Dit fenomeen benadrukt het belang van het gebruik van een aan de standaard beroepenclassificatie (CBS) gerelateerde indeling om te komen tot onderling vergelijkbare resultaten. Alleen de indeling van Mensen en Van den Burgh is gerelateerd aan de CBS-indeling. Verder verschaft het bestaande onderzoek geen inzicht in de specifieke beroepenstructuur van bio- en cognitieve psychologen.

Met betrekking tot de spreiding van psychologen over de verschillende bedrijfssectoren zijn wederom Krijnen (1976) en Mensen en Van den Burgh (1989) de belangrijkste bron van informatie. Krijnen laat zien dat tussen 1966 en 1975 de belangrijkste relatieve groei voor psychologen te vinden was bij de psychiatrische en algemene ziekenhuizen en bij de universiteiten, terwijl de grootste relatieve daling plaatsvond bij de maatschappelijke dienstverlening. Tabel 2.3 bevat de spreiding van sociologen en psychologen over de verschillende bedrijfstakken volgens Mensen en Van den Burgh.

Tabel 2.3. Verdeling van sociologen en psychologen over de belangrijkste sectoren volgens Mensen en Van den Burgh (1989)

sociologen

$\%$ psychologen

$\%$ organisatie-advies

overige zakelijke dienstverlening

universiteit

overig onderwijs

wetenschappelijk onderzoek

gezondheidszorg

welzijn/cultuur

belangenorganisaties

openbaar bestuur

overig niet zakelijke dienstverlening
6,1

5,1

18,7

7,1

7,1

24,7
0,3
7,9

6,3

9,5

21,4
8,7

6,3

9,5 
Vanuit deze invalshoek blijken de verschillen tussen sociologen en psychologen iets groter te worden. Met betrekking tot de werkterreinen onderwijs en onderzoek zijn de beide studierichtingen enigszins vergelijkbaar, maar een veel groter deel van de psychologen is werkzaam in de gezondheidszorg en in de zakelijke en niet-zakelijke dienstverlening. Sociologen zijn daarentegen veel vaker werkzaam in welzijn/cultuur, belangenorganisaties en in het openbaar bestuur.

De gegevens uit de literatuur met betrekking tot de spreiding van psychologen over bedrijfstakken hebben dezelfde tekortkomingen als de gegevens over de beroepenspreiding. Ze zijn alleen bekend voor de totale groep psychologen en niet specifiek voor de bio- en cognitieve psychologen. Ook hier sluiten de gehanteerde indelingen niet goed op elkaar aan. De gegevens in tabel 2.3 van Mensen en Van den Burgh (1989) zijn daarbij de enige bron die gerelateerd is aan de standaard bedrijfsindeling van het CBS.

\subsection{Werkloosheid}

In vrijwel alle publikaties over de arbeidsmarkt van psychologen wordt een poging gedaan om inzicht te krijgen in de werkloosheid onder psychologen of deelgroepen daarvan. Hierbij stuit men echter steeds op vergelijkbare problemen. Om een goed inzicht te krijgen in de ernst van de werkloosheidsproblematiek dient de werkloosheid berekend te worden als een percentage van het arbeidsaanbod. Voor het berekenen van een werkloosheidspercentage is derhalve vereist dat er gegevens bekend zijn over het aantal werkloze psychologen, maar ook gegevens over het aantal werkzame psychologen.

Het was tot voor kort relatief eenvoudig om absolute cijfers over de werkloosheid onder psychologen te verkrijgen. Aan de hand van de registratie van het arbeidsbureau kon het aantal ingeschreven werklozen geteld worden. Het arbeidsbureau maakte daarbij zelfs nog onderscheid tussen een aantal afstudeerrichtingen binnen de psychologie. Een probleem daarbij is wel de vervuiling van de bestanden van de arbeidsvoorziening (niet iedereen die als werkloos staat ingeschreven is ook daadwerkelijk werkloos). Bovendien is door de recente decentralisatie van de arbeidsvoorzieningorganisaties de uniformiteit bij het classificeren van de afstudeerrichtingen van de ingeschreven werklozen sterk verslechterd. Een steeds grotere groep academici wordt in verschillende regio's, gemakshalve, ingedeeld onder de noemer 'overige studierichtingen'. Thans is de vertekening van de cijfers hierdoor zo groot dat de gegevens niet meer gebruikt kunnen worden voor werkloosheidstellingen. Om toch gegevens over de werkloosheid onder psychologen te presenteren zal daarom volstaan moeten worden met de meest recente nog enigszins betrouwbare tellingen uit 1991 .

De bepaling van de omvang van de relevante groep psychologen in de beroepsbevolking is echter een nog groter probleem. Schaufeli en De Vries (1987) vergelijken de uitstroom van de universiteit met de absolute aantallen werklozen, maar deze methode levert zeer onbetrouwbare data op. Ook Holtzer (1984) en het Ministerie van Onderwijs en Wetenschappen gebruiken een dergelijke methode. De reconstructie van het Ministerie van Onderwijs en Wetenschappen is waarschijnlijk de betrouwbaarste, omdat hierbij éen systematiek voor alle academische 
studierichtingen is gevolgd die consistent is met de gegevens over de beroepsbevolking op geaggregeerd niveau.

In figuur 2.2 staan de resultaten van de berekeningen van het Ministerie van Onderwijs en Wetenschappen op basis van deze zogenaamde reconstructiemethode (Het Kristal-model, Dijkstra en Van de Donk, 1988). Dit zijn de berekeningen die ook in de HOOP-nota gebruikt worden ${ }^{7}$.

Figuur 2.2. Werkloosheidspercentages volgens Dijkstra en Van de Donk (1988) voor psychologen, sociologen en alle academici (1988 volgens O\&W, 1990)

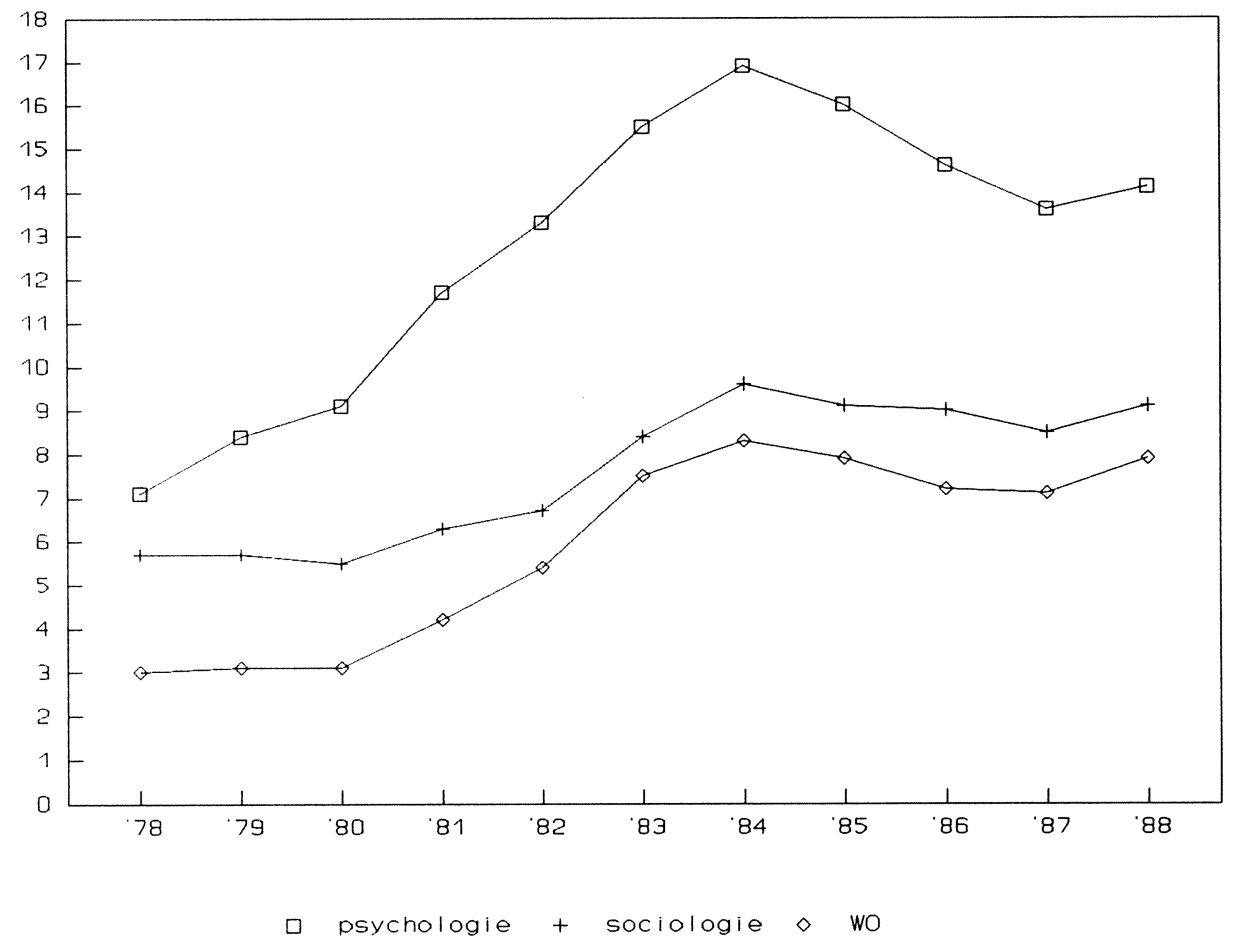

Hoewel de figuur enig inzicht geeft in de ontwikkelingen van de werkloosheidspercentages, moeten er vraagtekens gezet worden bij de betrouwbaarheid van met name de hoogte van deze cijfers en hun onderlinge verhoudingen. Met name afwijkingen in de participatiegraad bij bepaalde opleidingen kunnen leiden tot een ernstige vertekening van deze getallen. Desalniettemin kan geconcludeerd worden dat het werkloosheidspercentage van psychologen vrij hoog is, al is er vanaf 1984 sprake van een dalende ontwikkeling. Daarbij moet wel worden beseft dat het hier gaat om de totale groep psychologen, hetgeen betekent dat de relatief hoge werkloosheid geen betrekking hoeft te hebben op alle afstudeerrichtingen.

7. Zie bijvoorbeeld Ministerie van Onderwijs en Wetenschappen (1990). 



\section{HET AANBOD VAN PSYCHOLOGEN}

\subsection{Inleiding}

Voor een voorspelling van de arbeidsmarktsituatie voor bio- en cognitieve psychologen, die gebaseerd is op een manpower-benadering waarin verwachte tekorten of overschotten berekend worden, moet zowel een voorspelling van het aanbod als van de vraag gemaakt worden. De vraag kan opgesplitst worden naar uitbreidingsvraag en vervangingsvraag. Deze twee vraagcomponenten komen in hoofdstuk 4 en 5 aan bod. In dit hoofdstuk wordt ingegaan op het aanbod, dat wil zeggen de instroom van afgestudeerden op de arbeidsmarkt. In eerste instantie is vanzelfsprekend hierbij het kwantitatieve aanbod van belang (paragraaf 3.2). Als het accent echter verlegd wordt naar de arbeidsmarktperspectieven gegeven de achtergrond van de studenten is ook de samenstelling van het aanbod van belang. Dit komt aan de orde in paragraaf 3.3 .

\subsection{Het kwantitatief aanbod}

Voor een confrontatie van vraag en aanbod van psychologen is het nodig om inzicht te krijgen in de verwachte instroom in de studierichting psychologie en de daaraan gerelateerde uitstroom naar de arbeidsmarkt. Om zulke voorspellingen toe te kunnen spitsen op de arbeidsmarktsituatie van bio- en cognitieve psychologen dient verder een opsplitsing gemaakt te worden van dit aanbod over de verschillende afstudeerrichtingen, met name de aan bio- en cognitieve psychologie verwante richtingen versus de overige richtingen.

Tabel 3.1. In- en uitstroom voor psychologie op basis van referentie- en verdeelramingen van het Ministerie van Onderwijs en Wetenschappen (1992b)

\begin{tabular}{lrr}
\hline jaar & instroom & uitstroom \\
\hline & & 988 \\
$' 86$ & & 1.838 \\
$\prime 87$ & 1.392 & 1.247 \\
$\prime 88$ & 1.531 & 957 \\
$\prime 89$ & 1.444 & 914 \\
$\prime 90$ & 1.629 & 933 \\
$\prime 91$ & 1.725 & 992 \\
$\prime 93$ & 2.008 & 1.063 \\
$\prime 94$ & 2.077 & 1.237 \\
$\prime 95$ & 2.166 & 1.442 \\
$\prime 96$ & 2.239 & 1.679 \\
$\prime 90$ & 2.289 & 1.974 \\
$\prime 05$ & 2.368 & 2.075 \\
\hline
\end{tabular}

De belangrijkste bron voor de in- en uitstroom bij het wetenschappelijk onderwijs zijn de CBS- 
publicaties Statistiek van het wetenschappelijk onderwijs. Deze cijfers worden gepubliceerd op het niveau van studierichting. Dit betekent dat alleen de in- en uitstroom voor psychologie als geheel wordt gepubliceerd en er geen onderverdeling is naar afstudeerrichting. Op basis van deze cijfers maakt het Ministerie van Onderwijs en Wetenschappen (1992a) de Referentieramingen, waarin met behulp van demografische gegevens, trends in het keuzegedrag van studenten en trends in het numerieke rendement van de studierichtingen voorspellingen gemaakt worden van de toekomstige in- en uitstroom per onderwijssector. Vervolgens wordt ook door het Ministerie van Onderwijs en Wetenschappen (1992b) - deze prognose per onderwijssector verdeeld over de studierichtingen in de zogenaamde verdeelraming. Tabel 3.1 geeft de historische (CBS) en voorspelde in- en uitstroom voor psychologie tussen 1986 en 2005 op basis van de Verdeelraming 1992.

De tabel toont dat er een stijgende tendens in zowel de instroom als de uitstroom is te constateren bij psychologie. Deze geprognostiseerde groeiende belangstelling wordt deels veroorzaakt door een groeiende belangstelling voor de universiteit in het algemeen en deels door een verandering in de relatieve belangstelling voor psychologie. In figuur 3.1 is de ontwikkeling weergegeven van de instroom in psychologie. Daarnaast geeft het figuur aan hoe de instroom in psychologie zou zijn verlopen als een constant deel van de totale populatie studenten voor psychologie gekozen zou hebben. Als referentiepunt is hiervoor het jaar 1985 genomen. Ten slotte geeft het figuur aan hoe het verloop zou zijn geweest als een constant deel van de studenten gedrags- en maatschappijwetenschappen ${ }^{8}$ voor psychologie zou hebben gekozen.

De figuur laat ook duidelijk zien dat de belangstelling voor de gedrags- en maatschappijwetenschappen zeker tot 1997 sterker toeneemt dan de belangstelling voor academische studierichtingen in het algemeen. De belangstelling voor psychologie binnen het cluster gedrags- en maatschappijwetenschappen nam sinds 1985 echter minder snel toe dan de groep als totaal (De komende jaren zal dit verschil procentueel weer enigszins verkleinen). Hierdoor neemt psychologie in feite een tussenpositie in. De belangstelling groeit sneller dan die voor een academische studie in het algemeen, maar minder snel dan die voor gedrags- en maatschappijwetenschappen als totaal.

8. Het Ministerie van Onderwijs en Wetenschappen gebruikt de aanduiding gedrags- en maatschappijwetenschappen voor het cluster studierichtingen: sociologie, psychologie, politicologie, pedagogie, adragogie en geografie. Economie zit niet in dit cluster, zodat het overeenkomt met de ROA-aanduiding WO Sociaal-Cultureel. 
Figuur 3.1. Instroom bij psychologie, vergeleken met de totale instroom op de universiteit en de instroom bij gedrags- en maatschappijwetenschappen

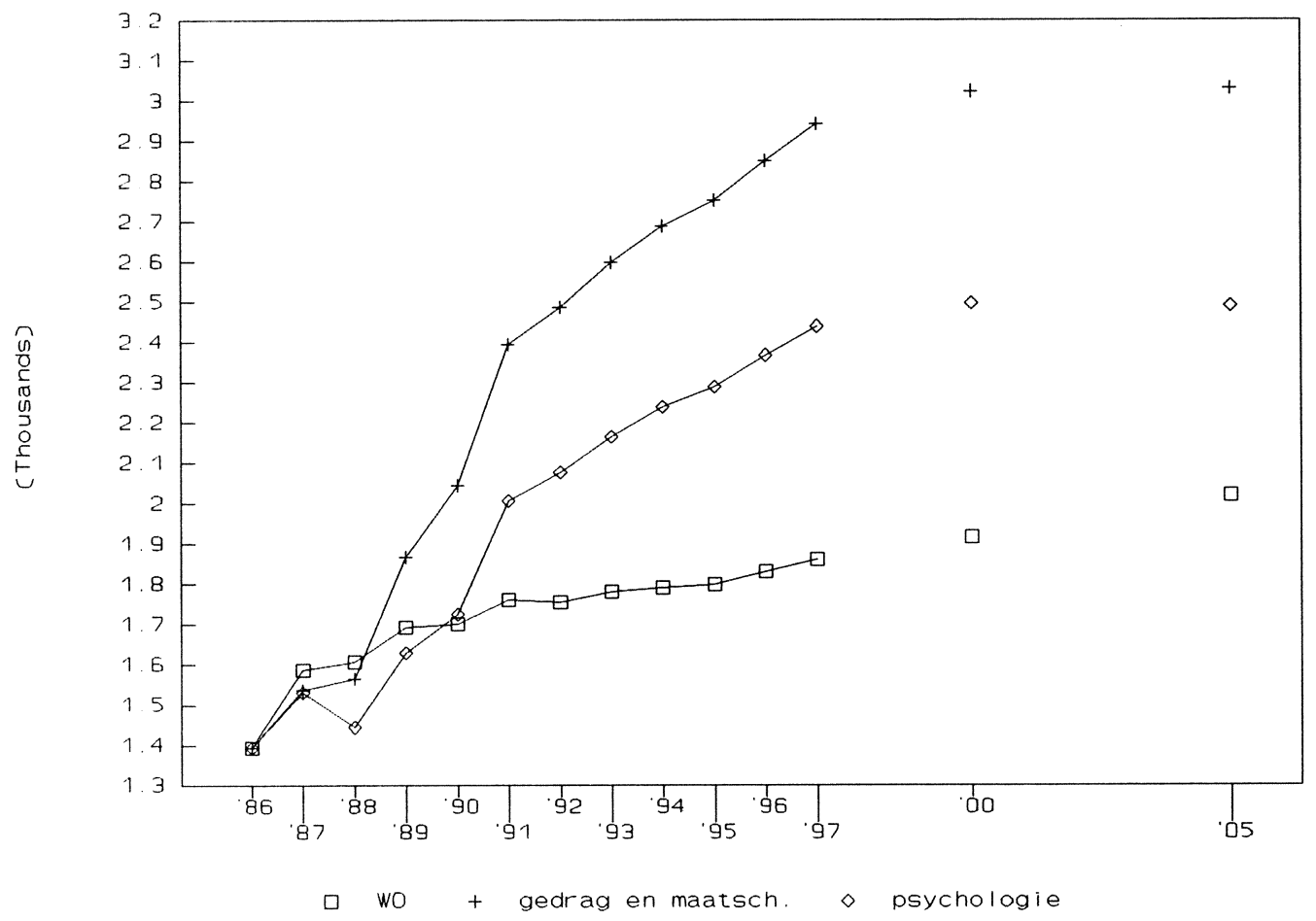

Bron: O\&W (1992b)

Figuur 3.2 geeft vergelijkbare informatie voor de uitstroom. De piek in de uitstroom rond 1988 wordt veroorzaakt door het gelijktijdig uitstromen van studenten van de oude stijl en nieuwe stijl opleidingen. Het patroon in de uitstroom is verder, zoals verwacht mocht worden, vergelijkbaar met dat van de instroom. Alleen treden de waargenomen ontwikkelingen hier met enkele jaren vertraging op. Van de instroom in 1993 bestaat $76 \%$ uit vrouwen. Dit percentage is hoger dan bij gedrags- en maatschappijwetenschappen in het algemeen (65\%) en bij de totale instroom op de universiteiten (49\%). In 2005 is het aandeel van vrouwen in de verwachte instroom bij psychologie gegroeid tot $85 \%$. Deze groei gaat gelijk op met de groei van vrouwelijke instroom van het universitair onderwijs in het algemeen (van $49 \%$ naar $62 \%$ ). 
Figuur 3.2. Uitstroom bij psychologie, vergeleken met de totale instroom op de universiteit en de instroom bij gedrags- en maatschapijwetenschappen

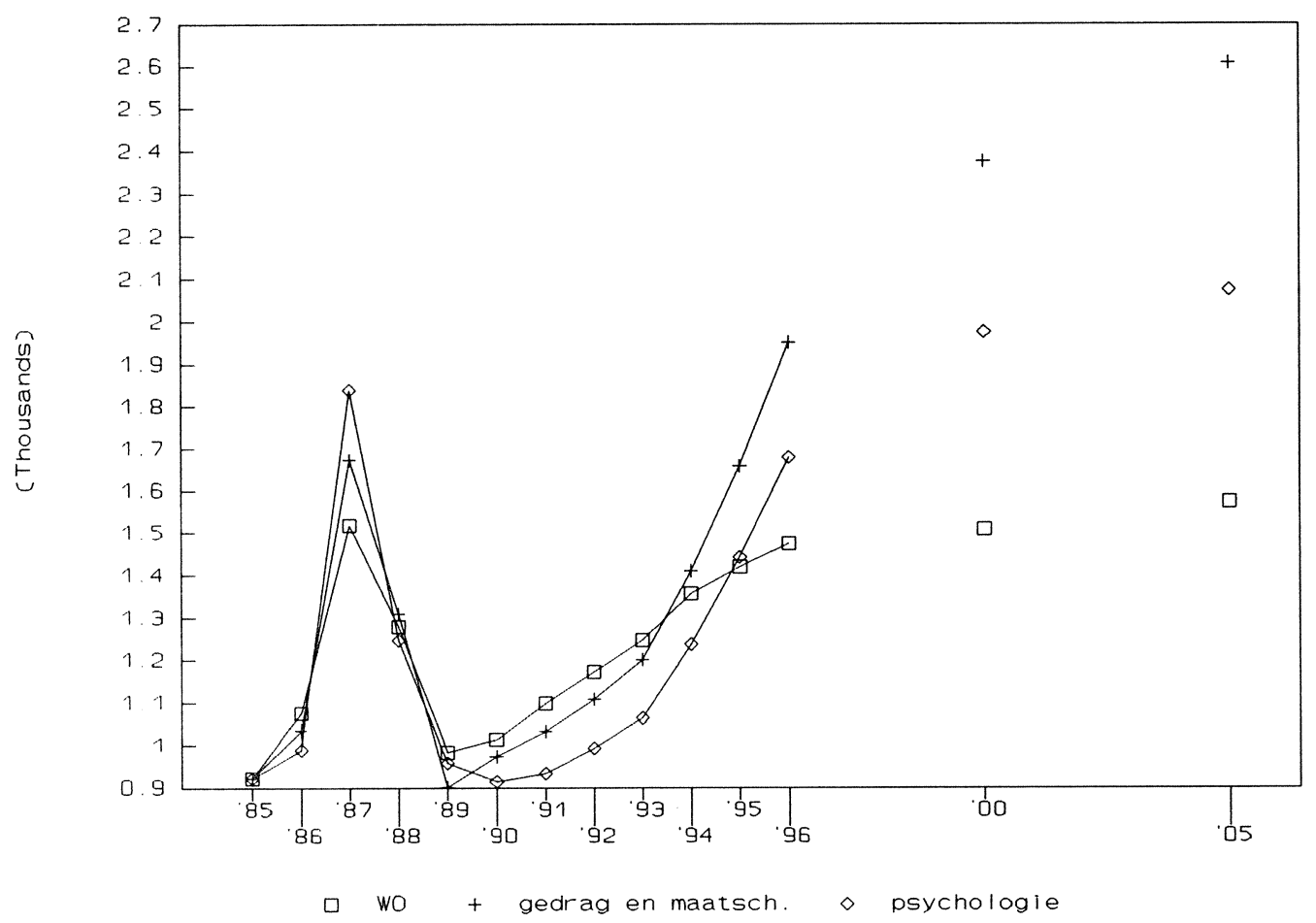

Bron: O\&W (1992b)

Voor een voorspelling van de arbeidsmarktsituatie voor bio- en cognitieve psychologie is het echter nodig om bovenstaande uitstroomcijfers voor psychologie toe te splitsen op de relevante afstudeerrichtingen binnen psychologie. In hoofdstuk 2 werden reeds enkele studies besproken die cijfers over de verdeling van de studentenaantallen over de studierichtingen geven. Deze cijfers zijn echter niet recent genoeg en bieden vaak niet de gewenste mate van detail met betrekking tot de aan bio- en cognitieve psychologie verwante afstudeerrichtingen. De meest voor de hand liggende methode om betere cijfers te krijgen over de verdeling van studenten over de afstudeerrichtingen is, conform Holtzer (1984), het benaderen van de studentenadministraties van de faculteiten in Nederland waar een psychologiestudie wordt gegeven. Omdat vergelijkbare afstudeerrichtingen bij verschillende faculteiten vaak zeer uiteenlopende namen hebben, moet hiervoor eerst een indeling gemaakt worden van de bestaande afstudeerrichtingen op basis van de vraag of ze al dan niet verwant zijn om de bioen cognitieve psychologie behoren.

Het benaderen van de faculteiten voor informatie over de verdeling van de afstudeerders kent twee nadelen. Ten eerste leert de ervaring met deze werkwijze dat faculteiten niet altijd volledig 
betrouwbare cijfers opgeven. Faculteiten weten vaak al niet goed hun allumni aan afstudeerrichtingen toe te wijzen, zeker niet als het om zeer specifieke richtingen gaat. Ten tweede is het meestal moeilijk om een tijdreeks te krijgen, omdat faculteiten vaak alleen beschikken over de recente cijfers. Mogelijk zal daarom volstaan moeten worden met verdeelcijfers over de huidige situatie, zodat hierin dus geen trends bepaald kunnen worden.

\subsection{Herkomst van het aanbod}

Voor het maken van een vergelijking tussen de vraag en het aanbod van bio- en cognitieve psychologen is het nodig om inzicht te hebben in de hoeveelheid studenten die uitstroomt uit het onderwijs. Voor een analyse waarin de arbeidsmarktperspectieven van studenten gerelateerd worden aan hun capaciteiten, om zodoende de toegevoegde waarde van een studierichting te bepalen, is echter inzicht nodig in de herkomst en de capaciteiten van de studenten die instromen. Goed inzicht in de groep studenten waaruit een opleiding rekruteert is van belang voor het onderling vergelijken van de arbeidsmarktpositie van opleidingen. Bij zo'n vergelijking dient men immers te corrigeren voor de herkomst of capaciteiten van de instroom. Indien men zou kunnen beschikken over individuele data, kon per studierichting een verband gelegd worden tussen deze individuele kenmerken bij het begin van een studie, zoals bijvoorbeeld de eindexamencijfers, en het latere functioneren op de arbeidsmarkt. Dit soort gegevens zijn echter niet voorhanden. Allereerst vraagt een dergelijke aanpak om systematische enquêtes onder afgestudeerden. Bovendien zouden de resultaten van een dergelijk afgestudeerdenonderzoek ook gekoppeld moeten worden aan de gegevens van de studentenadministratie, waarin doorgaans van de ingeschreven studenten de eindexamencijfers van de middelbare school bekend zijn. Zoals reeds werd vermeld, zijn de enige universiteiten waar systematisch arbeidsmarktonderzoek onder afgestudeerden wordt gedaan de Landbouwuniversiteit Wageningen en de Rijksuniversiteit Limburg. Beide universiteiten kennen (nog) geen studierichting psychologie, terwijl het onderzoek onder afgestudeerden van de faculteit Sociale Wetenschappen van Universiteit Utrecht zoals gezegd nog in de kinderschoenen staat.

Het ligt voor de hand dat indien de studierichting psychologie in Maastricht wordt opgericht, deze studierichting ook in het afgestudeerdenonderzoek van de RL zal participeren. Vanwege het bijzondere, $\beta$-gerichte, karakter van de nieuwe studierichting bio- en cognitieve psychologie, zou het interessant zijn om reeds bij aanvang van de studie de achtergrond van de ingestroomde studenten te bepalen. Voor een oordeel over de arbeidsmarktpositie van deze opleiding is het immers zeer relevant of men studenten werft die vergelijkbaar zijn met de instroom aan de bestaande psychologie-opleidingen, of dat de studenten beter vergelijkbaar zijn met de instroom in andere $\beta$-studierichtingen zoals natuurkunde, wiskunde, informatica of biologie.

Zoals in het eerste hoofdstuk reeds werd opgemerkt moet, indien vooral de traditionele psychologie-studenten in blijken te stromen, de meerwaarde van de nieuwe studierichting vooral gevonden worden in het verbeteren van de algemene arbeidsmarktperspectieven van deze groep studenten, door het versterken van het $\beta$-karakter van de studierichting. Een dergelijke opzet 
zou goed kunnen passen in het streven van de overheid het aantal $\beta$-opgeleiden te vergroten. Volgens met name het Ministerie van Economische Zaken kiezen te weinig studenten voor een technische opleiding. Willems en De Grip (1993) laten echter zien dat een groot deel van dit probleem al in een vroeg stadium van het onderwijsproces tot stand komt. Reeds op de middelbare school kiezen studenten voor een vakkenpakket dat niet typisch $\beta$-gericht is. Temeer daar dit voorsorteergedrag voor een belangrijk deel wordt bepaald door een waarschijnlijk reeds op jonge leeftijd gevormde interesse voor technische studierichtingen, zal een poging de belangstelling voor de traditionele $\beta$-richtingen te vergroten waarschijnlijk niet veel opleveren. Een goede strategie om toch wat aan het geconstateerde tekort aan $\beta$-opgeleiden te doen is dan het vergroten van het $\beta$-karakter van opleidingen in de marge van de technische studierichtingen.

Als studenten die instromen in de nieuwe studierichting bio- en cognitieve psychologie vooral afkomstig zijn uit de groep die toch al voor technische of natuurwetenschappelijke richtingen zouden hebben gekozen, is dit argument vanzelfsprekend niet meer van toepassing. De toename van afgestudeerden in deze $\beta$-richting zal dan ten koste gaan van de instroom in andere $\beta$ studierichtingen. In zo'n geval moet, bij het vaststellen van de arbeidsmarktrelevantie van de studierichting, vooral gekeken worden naar de mate waarin de studierichting inspeelt op veranderende behoeften aan de vraagkant.

Omdat bio- en cognitieve psychologie een studierichting zal zijn die zich duidelijk beweegt op het grensvlak van de sociale wetenschappen en de technische of natuurwetenschappelijke studierichtingen is het hier, voor het maken van zinvolle analyses over de arbeidsmarktperspectieven van de afgestudeerden, met name van belang na te gaan welk type student kiest voor deze nieuwe richting. Een dergelijk onderzoek kan echter pas goed uitgevoerd worden als de studie reeds van start is gegaan. Een eenvoudig onderzoek onder de nieuwe studenten zou nuttige informatie kunnen geven over de achtergronden van de instroom. Bijvoorbeeld met behulp van de vraag naar de voorkeur van de student in het geval hij niet bioen cognitieve psychologie in Maastricht had kunnen studeren, kunnen de qua instroom concurrerende studierichtingen getraceerd worden.

Vanwege het ontbreken van individuele data over de achtergronden van de instromende studenten moet in een onderzoek naar de toekomstige arbeidsmarktperspectieven van bio- en cognitieve psychologen een referentiegroep worden bepaald op studierichtingsniveau. Zelfs voor een dergelijke vergelijking ontbreken echter de benodigde data. Er is slechts weinig informatie beschikbaar over de achtergrondkenmerken van de instroom in het academisch onderwijs. Meerum Terwogt-Kouwenhoven (1990) geeft informatie over eindexamencijfers en scores op testen aan het begin van de studie van psychologiestudenten van de Universiteit van Amsterdam, maar bij gebrek aan vergelijkingsmateriaal met andere studierichtingen is dergelijke informatie ook niet goed bruikbaar. Willems en De Grip (1993) vroegen (onder andere) aan een aantal VWO-studenten zowel hun vakkenpakket als hun studieplannen. Tabel 3.2 geeft een overzicht van de resultaten op basis van deze enquête. Er wordt alleen gevraagd naar vrij grote opleidingscategorieen. Het vakkenpakket is getypeerd, op basis van de zogenaamde 
'doorstroomprofielen' die het Ministerie van Onderwijs en Wetenschappen beoogt in te gaan voeren. Het doorstroomprofiel 'Natuur en techniek' betreft de VWO-ers die zowel wiskunde (A of $B$ ) als natuurkunde en scheikunde in hun pakket hebben. 'Economie en maatschappij' betreft leerlingen die (1) Frans, Duits of Engels, (2) economie of handelskennis en (3) wiskunde (A of $B)$, maar geen biologie in hun pakket hebben. 'Cultuur en maatschappij'-leerlingen hebben de vakken (1) Frans of Duits en (2) geschiedenis en voor het profiel 'natuur en gezondheidszorg' moet men (1) wiskunde ( $A$ of $B$ ) en (2) biologie in het pakket hebben. Indien een vakkenpakket volgens deze criteria in meer dan één profiel zou passen, dan is het door Willems en De Grip ingedeeld bij het eerstgenoemde profiel van de hierboven gepresenteerde opsomming ${ }^{9}$.

ledere cel in tabel 3.2 bevat achtereenvolgens het absolute aantal, het rijpercentage en het kolompercentage.

Tabel 3.2. Relatie tussen vakkenpakket en voorgenomen studiekeuze van VWO-ers. Achtereenvolgens het absolute aantal, het rijpercentage en het kolompercentage

\begin{tabular}{|c|c|c|c|c|c|}
\hline & $\begin{array}{l}\text { natuur en } \\
\text { techniek }\end{array}$ & $\begin{array}{l}\text { natuur en } \\
\text { gezondheid }\end{array}$ & $\begin{array}{l}\text { economie en } \\
\text { maatschappij }\end{array}$ & $\begin{array}{l}\text { cultuur en } \\
\text { maatschappij }\end{array}$ & totaal \\
\hline \multirow[t]{3}{*}{ Sociaal-wetenschappelijk } & 2 & 5 & 6 & & 13 \\
\hline & $15 \%$ & $39 \%$ & $46 \%$ & & \\
\hline & $3 \%$ & $29 \%$ & $9 \%$ & & $7 \%$ \\
\hline \multirow[t]{3}{*}{ Technisch } & 22 & & 7 & & 29 \\
\hline & $76 \%$ & & $24 \%$ & & \\
\hline & $32 \%$ & & $10 \%$ & & $17 \%$ \\
\hline \multirow[t]{3}{*}{ Medisch } & 19 & 1 & & & 20 \\
\hline & $95 \%$ & $5 \%$ & & & \\
\hline & $28 \%$ & $6 \%$ & & & $11 \%$ \\
\hline \multirow[t]{3}{*}{ Economisch } & 4 & & 13 & 1 & 18 \\
\hline & $22 \%$ & & $72 \%$ & $6 \%$ & \\
\hline & $6 \%$ & & $19 \%$ & $4 \%$ & $10 \%$ \\
\hline \multirow[t]{3}{*}{ Juridisch } & 2 & & 4 & 7 & 13 \\
\hline & $15 \%$ & & $31 \%$ & $54 \%$ & \\
\hline & $3 \%$ & & $6 \%$ & $30 \%$ & $7 \%$ \\
\hline \multirow[t]{3}{*}{$\mathrm{HBO}$} & 14 & 8 & 22 & 8 & 52 \\
\hline & $27 \%$ & $15 \%$ & $42 \%$ & $15 \%$ & \\
\hline & $21 \%$ & $47 \%$ & $33 \%$ & $35 \%$ & $30 \%$ \\
\hline \multirow[t]{3}{*}{ Overige } & 5 & 2 & 8 & 3 & 18 \\
\hline & $28 \%$ & $11 \%$ & $44 \%$ & $17 \%$ & \\
\hline & $7 \%$ & $12 \%$ & $12 \%$ & $13 \%$ & $10 \%$ \\
\hline \multirow[t]{2}{*}{ Totaal } & 68 & 17 & 67 & 23 & 175 \\
\hline & $39 \%$ & $10 \%$ & $38 \%$ & $13 \%$ & $100 \%$ \\
\hline
\end{tabular}

Bron: ROA

De steekproef waarop tabel 3.2 gebaseerd is, is erg klein, maar de tabel geeft toch een

9. Daarnaast is het mogelijk dat een vakkenpakket aan geen van de vier genoemde criteria voldoet. Deze gevallen zijn buiten beschouwing gelaten. 
indicatief beeld van de typen studenten die voor bepaalde studierichtingen kiezen. Overigens moet opgemerkt worden dat het hier slechts gaat om de voorgenomen studiekeuze. Deze kan uiteraard afwijken van de uiteindelijke studiekeuze. Met name bij studierichtingen met een numerus fixus zal de uiteindelijke keuze afwijken van deze plannen.

De tabel laat zien dat de sociale wetenschappen vooral studenten aantrekken met de profielen natuur en gezondheid en economie en maatschappij. Opmerkelijk is dat van deze twee profielen een zeer groot deel kiest voor het hoger beroepsonderwijs. Voor de studierichting bio- en cognitieve psychologie lijkt met name het profiel natuur en gezondheid een relevante doelgroep, omdat deze leerlingen zowel wiskunde als biologie in hun pakket hebben. Van de groep leerlingen met dit profiel kiest in de (kleine) steekproef niemand voor een technische vervolgopleiding. Dit zou betekenen dat indien de studierichting bio- en cognitieve psychologie studenten met deze opleidingsachtergrond aan zou trekken zij een brugfunctie naar de techniek zou kunnen vervullen.

Concluderend kan gesteld worden dat er weinig relevante data beschikbaar zijn op grond waarvan de verwachte instroom bij bio- en cognitieve psychologie qua achtergrond vergeleken kan worden met de instroom in andere studierichtinge ${ }^{10}$. Een voor de hand liggende vooronderstelling om dit probleem te ondervangen is de aanname dat de instroom in bio- en cognitieve psychologie vergelijkbaar zal zijn met de instroom in de andere sociale wetenschappen, waarbij waarschijnlijk het accent zal liggen op het profiel natuur en gezondheid en minder op economie en maatschappij. Om resultaten met betrekking tot de arbeidsmarkt van Maastrichtse psychologen echter in een goed perspectief te kunnen plaatsen, is het belangrijk dat de informatie op dit punt uitgebreid wordt. Zeker als de studierichting daadwerkelijk van start gaat is het, zoals reeds werd aangegeven, daarom van belang om de opleidingsachtergrond van de ingeschreven studenten nader te onderzoeken. Deze informatie zou naderhand gecombineerd kunnen worden met de afgestudeerdeninformatie op basis van de RL-scanner en zou verder ook inzicht kunnen geven in de betekenis van het vakkenpakket (en de behaalde cijfers) voor de studievoortgang en de oorzaken van het voortijdige beëindigen van de studie.

10. Ook Webbink, De Jong, Oosterbeek en Roeteveld (1993) geven globale informatie over de achtergrond van studenten in bepaalde clusters academische opleidingen. 


\section{ALGEMENE ONTWIKKELINGEN AAN DE VRAAGKANT}

In het eerste hoofdstuk werd reeds aangegeven dat voor een beeld van de arbeidsmarktsituatie van bio- en cognitieve psychologen zowel informatie vereist is over de banen die specifiek zijn voor psychologen, als ook over de algehele ontwikkeling op de arbeidsmarkt. Aangezien een deel van de psychologiestudenten (al dan niet door de situatie op de arbeidsmarkt gedwongen) buiten de specifieke psychologie-beroepen terecht zal komen.

Voor het verkrijgen van een algeheel beeld van de arbeidsmarkt kan gebruik gemaakt worden van de Arbeidskrachtentelling (AKT, tot en met 1985) en de Enquête Beroepsbevolking (EBB, vanaf 1988). Beide enquêtes zijn grootschalige persoonsenquêtes ter vervanging van een volledige volkstelling. Bij de AKT werd 3 tot $5 \%$ van de bevolking ondervraagd, terwijl de EBB een steekproeffractie van $1 \%$ heeft.

Wanneer gebruik zou kunnen worden gemaakt van de AKT en de EBB voor een prognose van de arbeidsmarkt van bio- en cognitieve psychologen zouden deze prognoses goed aansluiten bij de prognoses naar opleiding en beroep die elke twee jaar door het ROA worden opgesteld ${ }^{11}$. Hierdoor zou er een koppeling gemaakt kunnen worden tussen de specifieke analyse van de toekomstige arbeidsmarktsituatie voor bio- en cognitieve psychologen en de meer algemene voorspellingen per opleiding, beroep en bedrijfstak.

Een van de grootste tekortkomingen van de AKT en de EBB voor het opstellen van prognoses voor bio- en cognitieve psychologen is dat de databestanden zoals die beschikbaar zijn alleen informatie voor de totale groep WO Sociaal-Cultureel geven. De belangrijkste studierichtingen die vertegenwoordigd zijn binnen deze groep zijn sociologie en psychologie. Deze studierichtingen kunnen niet direct onderscheiden worden, waardoor het al helemaal onmogelijk wordt om op basis van deze data rechtstreeks uitspraken te doen over een specifieke afstudeerrichting, zoals bio- en cognitieve psychologie.

In tabel 4.1 wordt een overzicht gegeven van het aantal werkenden met als opleiding WO Sociaal-Cultureel, per bedrijfssector. Deze bedrijfssectoren zijn ingedeeld op basis van de standaard bedrijfsindeling van het CBS. De meeste bedrijfssectoren zijn ingedeeld op het 1-digitniveau ('bedrijfstakken'), met uitzondering van bedrijfsklasse zakelijke dienstverlening (84) en de bedrijfsklassen overige dienstverlening (90-97), omdat daar de grootste groep sociale wetenschappers wordt aangetroffen. De laatste kolom van de tabel bevat de mutatie van het aantal werkenden tussen 1979 en 1985.

De groei van het totaal aantal werkzame sociale wetenschappers bedroeg tussen 1979 en 1985 $90 \%$. Een meer dan gemiddelde groei vond plaats in de dienstverlening lo.a. bank en verzekering en zakelijke dienstverlening), het onderwijs en de sociaal-culturele en culturele instellingen. Als de overige dienstverlening (bedrijfssector 9) en de zakelijke dienstverlening

11. Zie bijvoorbeeld ROA (1992a). 
(bedrijfsklasse 84), beschouwd worden als typische bedrijfstakken voor sociale wetenschappers, dan zijn in 1985 slecht 2.650 van de 39.050 personen $(6,8 \%)$ buiten dit domein werkzaam. Dit cijfer kan het belang voor analyses buiten de van sociale wetenschappen typische bedrijfsklassen relativeren.

Tabel 4.1. De verdeling van werkenden met een opleiding wO Sociaal-Cultureel volgens de Arbeidskrachtentelling over de bedrijfstakken

\begin{tabular}{|c|c|c|c|c|c|c|}
\hline \multicolumn{2}{|c|}{ bedrijfstak/klasse } & \multirow[t]{2}{*}{1979} & \multirow[t]{2}{*}{1981} & \multirow[t]{2}{*}{1983} & \multirow[t]{2}{*}{1985} & \multirow[t]{2}{*}{$\begin{array}{r}\text { mutatie } \\
1979-{ }^{-} 85 \\
\%\end{array}$} \\
\hline 0 & Landbouw en visserij & & & & & \\
\hline 1 & Delfstoffenwinning & & & & & \\
\hline $2 / 3$ & Industrie & 525 & 575 & 550 & 850 & +65 \\
\hline 4 & Openbare nutsbedrijven & & & & & \\
\hline 5 & Bouwnijverheid & & & & & \\
\hline 6 & Handel en horeca & 100 & 275 & 300 & 325 & +103 \\
\hline 7 & Transport en communicatie & 200 & 525 & 300 & 600 & +208 \\
\hline \multirow[t]{2}{*}{8} & Bank en verzekering, zakelijke & & & & & \\
\hline & dienstverlening & 1.050 & 1.800 & 2.350 & 2.400 & +132 \\
\hline 84 & Zakelijke dienstverlening & 775 & 1.300 & 1.925 & 1.700 & +119 \\
\hline 9 & Overige dienstverlening & 18.500 & 24.200 & 28.900 & 34.700 & +88 \\
\hline 90 & Openbaar bestuur & 7.525 & 3.700 & 4.375 & 5.900 & -21 \\
\hline 91 & Religieuze organisaties & & & & & \\
\hline 92 & Onderwijs & 5.350 & 9.325 & 10.400 & 14.100 & +163 \\
\hline 93 & Gezondheidsdiensten & & 3.650 & 4.175 & 3.600 & \\
\hline 94 & Maatschappelijke dienstverlening & 4.550 & 5.300 & 6.275 & 7.825 & +72 \\
\hline 95 & $\begin{array}{l}\text { Sociaal-culturele en culturele } \\
\text { instellingen }\end{array}$ & 500 & 1.200 & 2.275 & 2.050 & +311 \\
\hline 96 & Sport en recreatie & & & & & \\
\hline \multirow[t]{3}{*}{97} & Bedrijfs-en werknemersorganisaties, & & & & & \\
\hline & organisaties & & 950 & 825 & 1.000 & - \\
\hline & Totaal & 20.525 & 27.700 & 32.475 & 39.050 & +90 \\
\hline
\end{tabular}

Bron CBS; aantallen lager dan 250 zijn weggelaten

Tabel 4.2 bevat vergelijkbare informatie over de beroepen waarin de werkenden met de opleiding WO Sociaal-Cultureel werkzaam zijn. Deze beroepen zijn ingedeeld volgens de ROAberoepenclassificatie ${ }^{12}$. In de tabel zijn alleen de beroepen weergegeven waarvoor in minstens drie van de vier AKT-jaren het aantal werkenden groter was dan 100.

De tabel laat zien dat de grootste groep sociale wetenschappers werkzaam is als sociale wetenschapsbeoefenaar. Dit betreft ongeveer 1 van de 3 werkenden met de opleiding WO Sociaal-Cultureel. Daarnaast is een aanzienlijke groep werkzaam als docent $(17 \%)$. Een

12. De ROA-beroepenclassificatie is gekoppeld aan de beroepenindeling van het CBS, op basis van de opleidingen van de werkenden in deze beroepen (zie Dekker, De Grip en Van de Loo (1990)). Binnenkort stapt het CBS over op een classificatie met een vergelijkbare opzet. 
probleem van de informatie op basis van de AKT en EBB blijft dat er geen onderscheid gemaakt wordt tussen psychologen en andere sociale wetenschappers.

Tabel 4.2. De verdeling van werkenden met opleiding WO Sociaal-Cultureel volgens de Arbeidskrachtentelling over de beroepen

\begin{tabular}{|c|c|c|c|c|}
\hline ROA-beroepsklasse & 1979 & 1981 & 1983 & 1985 \\
\hline Docenten voortgezet en hoger onderwijs & 4.225 & 5.100 & 6.250 & 6.825 \\
\hline Schoolhoofden e.a. onderwijskundige beroepen & 900 & 1.225 & 1.400 & 2.075 \\
\hline Directeuren, leidinggevende functies produktie & 350 & 925 & 1.375 & 1.400 \\
\hline Hogere leidinggevenden & 975 & 1.075 & 1.050 & 1.425 \\
\hline Secretaressen, typisten & 125 & 225 & 300 & 300 \\
\hline Commercieel-administratieve employees & & 425 & 1.500 & 1.675 \\
\hline Accountants, economen e.a. economische specialisten & 350 & 175 & 400 & 275 \\
\hline $\begin{array}{l}\text { Leden en leidinggevenden openbaar bestuur, beleids- } \\
\text { ambtenaren }\end{array}$ & 925 & 1.125 & 1.375 & 1.325 \\
\hline Auteurs, journalisten, nieuwslezers, presentatoren & 175 & 75 & 400 & 550 \\
\hline Bibliothecarissen, archivarissen, conservatoren & 100 & 350 & 200 & 475 \\
\hline Personeels- en beroepenspecialisten, arbeidsbemiddelaars & s 225 & 325 & 300 & 400 \\
\hline Maatschappelijk werkers, reclasseringsambtenaren & 1.250 & 3.175 & 4.575 & 4.900 \\
\hline Sociale wetenschapsbeoefenaren & 8.925 & 11.525 & 9.075 & 13.425 \\
\hline Overige sociaal-culturele en commerciele vakspecialisten & 600 & 100 & 1.525 & 1.575 \\
\hline Totaal & 20.525 & 27.700 & 32.475 & 39.050 \\
\hline
\end{tabular}

Bron: CBS (AKT)

Om dit onderscheidingsprobleem te verhelpen zou de informatie over de bedrijfsklasse of het beroep van de psychologen niet betrokken moeten worden uit de reeds beschikbare AKT- of EBB-bestanden, maar zouden de oorspronkelijke data op individueel niveau gebruikt moeten worden. Op zich is dat mogelijk, maar gezien het beleid van het CBS om informatie op basis van de EBB alleen nog te verstrekken voor zover de cellen een inhoud hebben die groter is dan 5.000 (en alleen op 1.000-tallen afgeronde gevens te verstrekken), zou dit niet veel opleveren. Voor de EBB 1991 is bekeken wat een dergelijke analyse op zou leveren. Het blijkt dat in 1991 16.000 psychologen werkzaam waren, waarvan 8.000 mannen en 7.000 vrouwen. In geen enkele bedrijfsklasse (ROA-indeling) kwamen meer dan 5.000 psychologen voor en alleen in beroep 85, de sociale-wetenschapsbeoefenaren, bevonden zich 5.000 werkenden met een psychologie-opleiding. In alle andere beroepen waren minder psychologen werkzaam. Het heeft dus weinig zin deze data te verzamelen.

Om toch zinnige uitspraken te kunnen doen over de arbeidsmarkt voor bio- en cognitieve psychologen in zijn geheel moet derhalve een andere oplossing gevonden worden. Een mogelijkheid is het op basis van gegevens uit bijvoorbeeld het onderzoek van Mensen en Van den Burgh (1989) of op basis van het NIP-ledenbestand, opsplitsen van de gegevens voor WO Sociaal-Cultureel naar studierichting. 



\section{ONTWIKKELINGEN BINNEN DE BEROEPSGROEP}

\subsection{Inleiding}

De geschetste mogelijkheden in hoofdstuk 4 op basis van data uit de AKT en EBB van het Centraal Bureau voor de Statistiek en gekoppeld daaraan de arbeidsmarktvoorspellingen van het ROA voor de periode 1993-1989 hebben vooral betrekking op de algehele arbeidsmarktsituatie voor personen met een sociaal-wetenschappelijke opleiding. Door de aard van de data zullen analyses die op basis hiervan gemaakt worden ook altijd een vrij globaal en slechts indicatief karakter hebben. Een voordeel van het gebruik van de AKT en EBB is echter wel dat zij als basis kunnen dienen voor prognoses die inzicht kunnen geven in de arbeidsmarktperspectieven van afgestudeerden over de gehele arbeidsmarkt. Op zich zijn deze perspectieven buiten de psychologie-beroepen ook van belang. Omdat echter een groot gedeelte van de afgestudeerde sociale wetenschappers in de bedrijfstakken zakelijke en overige dienstverlening terecht komt kunnen meer specifieke data met betrekking tot het werkveld van degenen die binnen deze sectoren werkzaam zijn, ook in dit opzicht, een belangrijke rol spelen.

Als echter het accent verlegd wordt van de arbeidsmarktkansen van de afgestudeerden op zich, naar de vraag of de nieuwe studierichting bio- en cognitieve psychologie inspeelt op veranderende behoeften in de vraag binnen het beroepsveld van psychologen, wordt het überhaupt minder belangrijk dat de gebruikte data de hele arbeidsmarkt afdekken. Daarentegen wordt het relevanter om data te hebben die gedetaileerde informatie geven met betrekking tot de specifieke psychologie-beroepen. Net als bij het onderzoek naar de arbeidsmarkt voor klinische psychologen (Beekman en Heijke, 1990) kan hierbij de ledenadministratie van een psychologenvereniging zeer bruikbare informatie geven. Er zijn twee verenigingen van psychologen die voor het opstellen van een arbeidsmarktprognose voor de vraag naar afgestudeerden in de bio- en cognitieve psychologie relevant lijken te zijn. Dat zijn het Nederlands Instituut van Psychologen (NIP) en de Nederlandse Vereniging voor Neuropsychologie.

Het Nederlands Instituut van Psychologen is een beroepsvereniging waarvan, volgens eigen opgave, ongeveer de helft van de in Nederland als psycholoog werkzame personen lid is ${ }^{13}$. In de klinische richtingen is er sprake van een kleine oververtegenwoordiging. Ongeveer $60 \%$ van de klinisch psychologen is lid. Dat betekent dat in de overige richtingen het lidmaatschap gemiddeld onder de 50\% moet liggen. Naar aanleiding van het onderzoek naar de arbeidsmarkt van klinisch psychologen (Beekman en Heijke, 1990) is in 1989 de ledenadministratie van het NIP bruikbaar gemaakt voor dergelijke arbeidsmarktanalyses. De administratie is eenvoudig toegankelijk voor onderzoeksanalyses en de bedrijven waar de psychologen werkzaam zijn, zijn

13. Het NIP heeft ongeveer 5.000 leden, terwijl er volgens de EBB 16.000 werkzame psychologen zijn. Dit betekent dat volgens de NIP ongeveer 6.000 (38\%) van de werkzame psychologen buiten het vakgebied werkzaam zijn. Deze schatting ligt aanmerkelijk hoger dan de schatting op grond van de bedrijfsindeling in hoofdstuk 4 . 
geclassificeerd volgens de Standaard Bedrijfsindeling van het Centraal Bureau van de Statistiek. Deze classificatie is sindsdien gehandhaafd. Aangezien het ledenbestand van 1989 direct beschikbaar is, kan in paragraaf 5.2 getoond worden wat de mogelijkheden zijn van dit ledenbestand. Voor een verdere analyse van de ontwikkelingen op het gebied van bio- en cognitieve psychologie dient een recenter bestand gebruikt te worden. Zeker in combinatie met het bestand van 1989 kan dit NIP-bestand echter veel nuttige informatie over de verwachte toekomstige arbeidsmarkt voor bio- en cognitieve psychologen opleveren.

De ledenadministratie van de Nederlandse Vereniging voor Neuropsychologie blijkt niet bruikbaar te zijn voor het maken van arbeidsmarktvoorspellingen. Hoewel de vereniging zich richt op een voor het onderzoek zeer relevante doelgroep zijn er enkele bezwaren die het gebruik van deze ledenadministratie onmogelijk maken. Ten eerste is de Nederlandse vereniging voor Neuropsychologie geen beroepsvereniging zoals het NIP, maar een wetenschappelijke vereniging. De doelstelling om de vereninging is dan ook niet primair het dienen van de belangen van de leden, maar het stimuleren van het betreffende wetenschapsgebied: de neuropsychologie. Daardoor heeft de vereniging niet alleen psychologen als lid, maar zijn mensen met zeer uiteenlopende achtergronden die interesse hebben in de neuropsychologie lid van de vereniging. Ook houdt de vereniging alleen het adres van haar leden bij en geen andere gegevens met betrekking tot het beroep van haar leden. Ten tweede staan de reglementen van de vereniging niet toe dat de ledenadministratie voor iets anders gebruikt wordt dan waarvoor hij oorspronkelijk bedoeld is. Volgens de Nederlandse Vereniging voor Neuropsychologie is het derhalve ook niet mogelijk om via de ledenadministratie van de vereniging enquêtes te versturen naar de leden.

\subsection{Het NIP-ledenbestand}

Het ledenbestand van het Nederlands Instituut van Psychologen is een databron die zeer gedetailleerde informatie verschaft over de werkkring van psychologen. De bruikbaarheid van deze data blijkt reeds uit de studies van bijvoorbeeld Holtzer (1984) en Beekman en Heijke (1990) die onder andere gebaseerd zijn op het NIP-ledenbestand. Het voornaamste bezwaar tegen het gebruik van deze data is de mogelijke niet-representativiteit. Bijna alle leden van de vereniging zijn werkzaam als psycholoog, zodat alle afgestudeerde psychologen die in een ander beroep terecht zijn gekomen niet vertegenwoordigd zijn in het ledenbestand. Verder zijn klinisch psychologen, volgens opgave van de vereniging, enigszins oververtegenwoordigd, maar de verschillen zijn niet zo groot dat dit tot ernstige problemen zal leiden. Zeker als het gaat om de ontwikkeling in de beroepsgroep zal deze oververtegenwoordiging geen grote invloed op de resultaten hebben.

Het feit dat het ledenbestand vooral betrekking heeft op de als psycholoog werkzame personen en niet zozeer de afgestudeerde psychologen in het algemeen, maakt dat de informatie vooral gebruikt kan worden voor het beschrijven van de (ontwikkelingen in de) vraagkant van de psychologenmarkt. Het aantal psychologen dat al dan niet noodgedwongen werk buiten de psychologie vindt blijft buiten beschouwing. 
Het ledenbestand van december 1989 is reeds beschikbaar bij het ROA. Daarom zal aan de hand van dit bestand beschreven worden wat de mogelijkheden zijn van het gebruik van het NIP-ledenbestand. Voor het opstellen van prognoses met betrekking tot de toekomstige arbeidsmarkt voor bio- en cognitieve psychologen zal, zoals gezegd, echter gebruik gemaakt moeten worden van een meer recente versie van het ledenbestand. Vergelijking van de 1989versie en het nieuwe ledenbestand kan daarbij nog extra informatie opleveren.

Het ledenbestand, zoals dat thans beschikbaar is bevat per lid van de beroepsvereniging de volgende variabelen:

- Geboortedatum;

- Geslacht;

- Postcode werknemer;

- Betaald werk?;

- Aantal uren in dienstverband;

- Zelfstandig gevestigd?;

- Datum afstuderen;

- Afstudeerrichting;

- Datum afstuderen eerste fase opleiding;

- Specialisatie;

- Klinische registratie;

- Postcode werkgever;

- Werkgever gecodeerd volgens de Standaard Bedrijfsindeling van het C.B.S.

Verder worden in het databestand de volgende werkvelden onderscheiden:

- Zwakzinnigenzorg;

- Forensisch;

- Psychotheraptie;

- Psychiatrie;

- Gerontologie;

- Sociaal;

- Arbeids en Organisatie;

- Onderwijs;

- Beroepskeuze;

- Kinder en jeugd;

- Wetenschappelijk onderzoek.

In het ledenbestand van 1989 zijn 5.082 leden opgenomen. Tabel 5.1 geeft een overzicht van de afstudeerrichtingen die voorkomen in het NIP-ledenbestand, met daarachter het aantal leden met deze opleidingsachtergrond en een voorlopige aanduiding van de afstudeerrichtingen aan bio- en cognitieve psychologie verwant zijn. Om aan te geven welke indeling gehanteerd wordt in de NIP-ledenadministratie zijn de nauw verwante afstudeerrichtingen in tabel 5.1 overigens niet samengevoegd. Als de NIP-data in het hoofdonderzoek gebruikt zullen worden, zal er in 
overleg met enkele psychologen die direct betrokken zijn bij de nieuwe psychologiestudie een definitieve indeling gemaakt moeten worden. Eventueel kan in zo'n indeling een verder onderscheid gemaakt worden naar zeer sterk aansluitende studierichtingen, enigszins aansluitende studierichtingen en niet aansluitende studierichtingen.

Tabel 5.1. Verdeling van de NIP-leden in 1989 over afstudeerrichting en indeling van afstudeerrichtingen met betrekking tot relevantie voor bio- en cognitieve psychologie

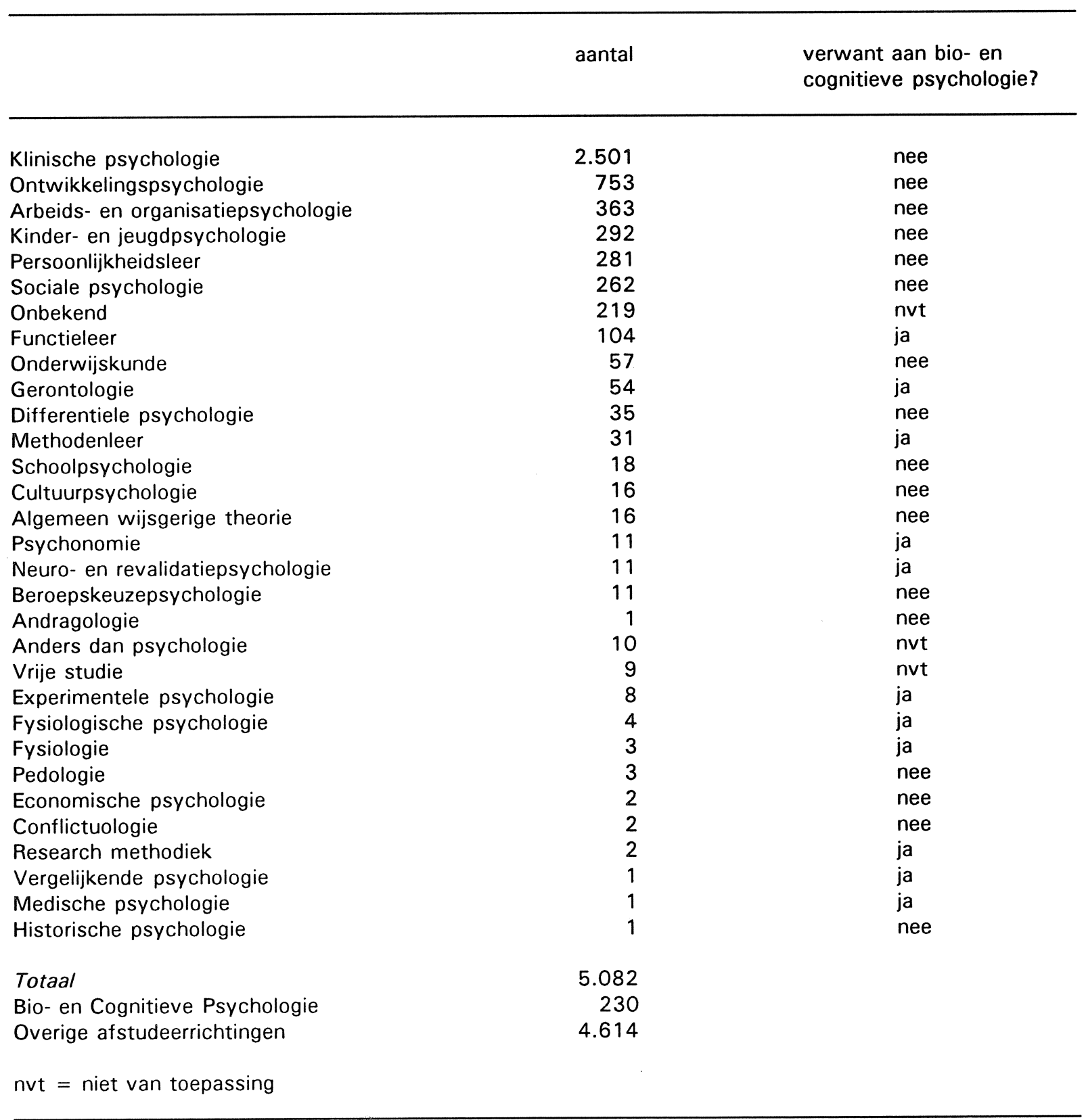

Bron: NIP

Het overgrote deel van de NIP-leden heeft, volgens de hier gehanteerde indeling, een afstudeerrichting gevolgd die niet verwant is aan de bio- en cognitieve psychologie. Slechts 230 van de 5.082 leden behoren tot een van de verwante afstudeerrichtingen. Op zich is deze groep 
groot genoeg voor het doen van statistisch zinvolle uitspraken. Deze uitspraken zullen echter, doordat de groep zo klein is, weinig specifiek van aard kunnen zijn. Bovendien is het niet zinvol de beroepsbeofenaren met een aan bio- en cognitieve psychologie verwante opleidingsachtergrond nog verder op te splitsen in deelpopulaties. Voor de groep psychologen die niet behoort tot de Maastrichtse doelgroep kan een dergelijke opsplitsing, gezien de aantallen, wel plaatsvinden. Hierdoor zouden in het hoofdonderzoek voorspellingen gedaan kunnen worden van de arbeidsmarktperspectieven van de studie psychologie in de volle breedte, waardoor de analyse niet beperkt blijft tot de bio- en cognitieve psychologen. Uit het oogpunt van een mogelijke vergelijking tussen de afstudeerrichtingen, zou dit een interessante, maar toch relatief eenvoudige uitbreiding van het onderzoek inhouden, waarvoor wellicht ook in andere kringen belangstelling bestaat.

Een vergelijking van de afstudeerrichtingen in het NIP-bestand en de gegevens van Holtzer (1984) en Krijnen (1976) over de uitstroom van afgestudeerde psychologen per afstudeerrichting duidt op enkele discrepanties. Volgens Holtzer is $40 \%$ van de afgestudeerden klinisch psycholoog terwijl dit er volgens het NIP-bestand $49 \%$ zijn. Ontwikkelingsleer zorgt voor $27 \%$ van de afgestudeerden en slechts voor $15 \%$ NIP-leden. Sociale psychologie levert $8 \%$ van de afstudeerders en $7 \%$ van de NIP-leden. Functieleer, tenslotte, zorgt voor $6 \%$ van de afstudeerders en voor slechts $2 \%$ van de NIP-leden.

Deze discrepantie kan verschillende oorzaken hebben. Ten eerste kan er een ondervertegenwoordiging zijn in het NIP-bestand van de afgestudeerden in de richting functieleer. Ten tweede kan het zo zijn dat veel studenten functieleer werkzaam zijn in functies die buiten het psychologie-beroepsdomein vallen. Ten derde sluiten de gehanteerde classificaties niet volledig op elkaar aan. In het NIP-bestand worden veel meer richtingen onderscheiden dan in de publikatie van Holtzer (1984). Als alle aan bio- en cognitieve psychologie gerelateerde richtingen bij Holtzer als functieleer geclassificeerd zijn, sporen de percentages beter met elkaar $(4,5 \%$ in het NIP-bestand tegenover $5,8 \%$ afgestudeerden).

Er zal bij een hoofdonderzoek derhalve goed gekeken moeten worden naar de aansluiting tussen beide data-bronnen. De gegevens moeten daarbij gecorrigeerd worden voor het jaar van afstuderen en de gegevens over de aantallen afgestudeerden moeten verder verbijzonderd worden.

Door de gedetailleerdheid van de informatie is het NIP-ledenbestand een zeer geschikte bron voor het opstellen van prognoses over de arbeidsmarkt van psychologen. Als er naast het reeds beschikbare bestand van 1989, de beschikking komt over een recenter bestand kunnen deze data dienen om enkele belangrijke ontwikkelingen binnen de psychologie te traceren. Ten eerste kunnen verschuivingen in de werkgelegenheid per bedrijfstak getraceerd worden. Binnen een bedrijfstak kunnen vervolgens de ontwikkelingen in de relatieve positie van de onderscheiden afstudeerrichtingen worden vastgelegd. Door de sectorontwikkelingen te koppelen aan ROA- en 
CPB-prognoses voor de verwachte ontwikkeling per bedrijfstak ${ }^{14}$, kan op grond hiervan een voorspelling gemaakt worden van de werkgelegenheid voor bepaalde groepen psychologen in bepaalde bedrijfstakken. Door aggregatie kunnen deze cijfers een beeld geven van de te verwachten totale vraag naar bio- en cognitieve psychologen in 1998. Door de aard van de NIPdata betreft dit dan wel alleen de vraag naar psychologen in psychologieberoepen. Omdat de NIP-gegevens weinig informatie bevatten over psychologen die buiten het vakspecifieke beroepsveld werkzaam zijn, zal voor een voorspelling van de ontwikkeling buiten dit beroepsveld teruggevallen moeten worden op de EBB-data die een veel grover beeld geven van de ontwikkelingen op de arbeidsmarkt (zie hoofdstuk 4). Verder moet, op grond van andere databronnen, een correctie gemaakt worden voor het feit dat binnen het vakspecifieke beroepsveld een groot deel van de (werkzame) psychologen geen lid is van het NIP. In totaal moet het aantal werkzame psychologen in 1991 weer uitkomen op 16.000 zoals blijkt uit de EBB.

Tabel 5.2 geeft een overzicht van de sectoren waarin leden van het NIP werkzaam zijn. Een vergelijking met tabel 4.1 geeft aan dat de NIP-leden ten opzichte van sociale wetenschappers in de AKT inderdaad zijn ondervertegenwoordigd in de bedrijfstakken buiten de zakelijke en overige dienstverlening. Dit wordt waarschijnlijk veroorzaakt door de lage organisatiegraad van de niet als psycholoog werkzame personen. Verder zitten er binnen de bedrijfstakken 8 en 9 discrepanties tussen beide tabellen. De NIP-leden zijn oververtegenwoordigd in de bedrijfsklasse gezondheidsdiensten (93) en maatschappelijke dienstverlening (94) en ondervertegenwoordigd in openbaar bestuur (90), onderwijs (92) en sociaal-culturele en culturele instellingen (95). Dit verschil is waarschijnlijk voor een groot deel veroorzaakt door het onderscheid tussen sociologen en psychologen en voor het onderwijs wellicht opnieuw door de lage NIPlidmaatschapsgraad van psychologen in het onderwijs. Slechts $11,5 \%$ van de NIP-leden is werkzaam in het onderwijs, terwijl volgens Mensen en Van den Burgh (1989, zie tabel 2.3) dit ongeveer $30 \%$ moet zijn. Dit verschil kan echter mede veroorzaakt zijn doordat de steekproef van Mensen en Van den Burgh alleen pas afgestudeerde psychologen bevat.

Op grond van soortgelijke vergelijkingen tussen de beschikbare databronnen is het mogelijk een correctie voor dergelijke over- of ondervertegenwoordigingen in zowel de EBB als de NIPledenlijst aan te brengen. Via een koppeling, op basis van de AKT of EBB, van bedrijfstak naar beroep, lijkt het dan ook zeer goed mogelijk een verband te leggen tussen de ontwikkelingen binnen de psychologieberoepsgroep op basis van het NIP-ledenbestand en de ROA-prognoses per beroep. Op grond hiervan kan bekeken worden of bio- en cognitieve psychologen vergeleken met andere psychologen in beroepen terecht komen met relatief gunstige perspectieven.

De tabel geeft verder aan in welke bedrijfstakken de bio- en cognitieve psychologen relatief goed of juist relatief slecht vertegenwoordigd zijn vergeleken met de totale groep NIP-leden. In de bedrijfstakken onderwijs en wetenschappelijk onderwijs, in verpleeghuizen en in bedrijfs- en

14. Op grond van de uitkomsten die ten grondslag lagen aan de meerjarenverkenning in het Centraal Economisch Plan 1993, en de ROA-prognoses naar opleiding en beroep die dit najaar beschikbaar zullen komen. 
werknemersorganisaties en researchinstellingen bevinden zich significant meer dan gemiddeld bio- en cognitieve psychologen. Bij psychiatrische inrichtingen, maatschappelijke dienstverlening en sociaal medische, -psychologische, -pedagogische diensten zijn er significant minder bio- en cognitieve psychologen aanwezig. Maatschappelijke dienstverlening is weliswaar een voor bioen cognitieve psychologie zeer belangrijke bedrijfsklasse, maar vergeleken met de totale groep psychologen is dit aantal gering.

Tabel 5.2. Aantal NIP-leden en het aantal bio- en cognitieve psychologen daarvan per bedrijfstak

Sector:

SBI bedrijfstak/-klasse/-groep

NIP bio- en relatief belang

cognitieve bio- en

psychologie cognitieve

in NIP psychologie

t.o.v. overige

richtingen

$\begin{array}{ll}0 & \text { Landbouw en visserij } \\ 1 & \text { Delfstoffenwinning } \\ 2 / 3 & \text { Industrie } \\ 4 & \text { Openbare nutsbedrijven } \\ 5 & \text { Bouwnijverheid } \\ 6 & \text { Handel en horeca } \\ 7 & \text { Transport en communicatie } \\ 8 & \text { Bank en verzekering, zakelijke dienstverlening } \\ 8461 & \text { Economische adviesbureaus } \\ 9 & \text { Overige dienstverlening } \\ 90 & \text { Openbaar bestuur } \\ 91 & \text { Religieuze organisaties } \\ 92 & \text { Onderwijs } \\ 9271.1 & \text { Wetenschappelijk onderwijs } \\ 93 & \text { Gezondheidsdiensten } \\ 931 & \text { Ziekenhuizen } \\ 932 & \text { Psychiatrische inrichtingen } \\ 933 & \text { Zwakzinnigeninrichtingen } \\ 934 & \text { Verpleeghuizen } \\ 94 & \text { Maatschappelijke dienstverlening } \\ 9441 & \text { Sociaal medische, -psychologische, -pedagogische } \\ & \text { diensten } \\ 95 & \text { Sociaal-culturele en culturele instellingen } \\ 96 & \text { Sport en recreatie } \\ 97 & \text { Bedrijfs- en werknemersorganisaties, research- } \\ & \text { instellingen, overige sociale organisaties }\end{array}$

$597 \quad 57$

Bron: NIP. Aantallen lager dan 10 zijn weggelaten

Naast de prognoses per sector van de uitbreidingsvraag voor bio- en cognitieve psychologie, kan op basis van de NIP-data ook een voorspelling van de vervangingsvraag opgesteld worden. Door een koppeling van de twee bestanden (1989 en een recent jaar) kan de leeftijdsopbouw van het ledenbestand tussen de twee meetmomenten vergelijken worden en kan de historische vervangingsvraag gecalculeerd worden. De hierbij gemeten procentuele uitstroom per 
leeftijdsgroep kan geëxtrapoleerd worden, om zo een voorspelling van de toekomstige vervangingsvraag te krijgen.

Figuur 5.1. Bio- en cognitieve psychologen in NIP-bestand naar jaar van afstuderen, vergeleken met totale NIP-bestand

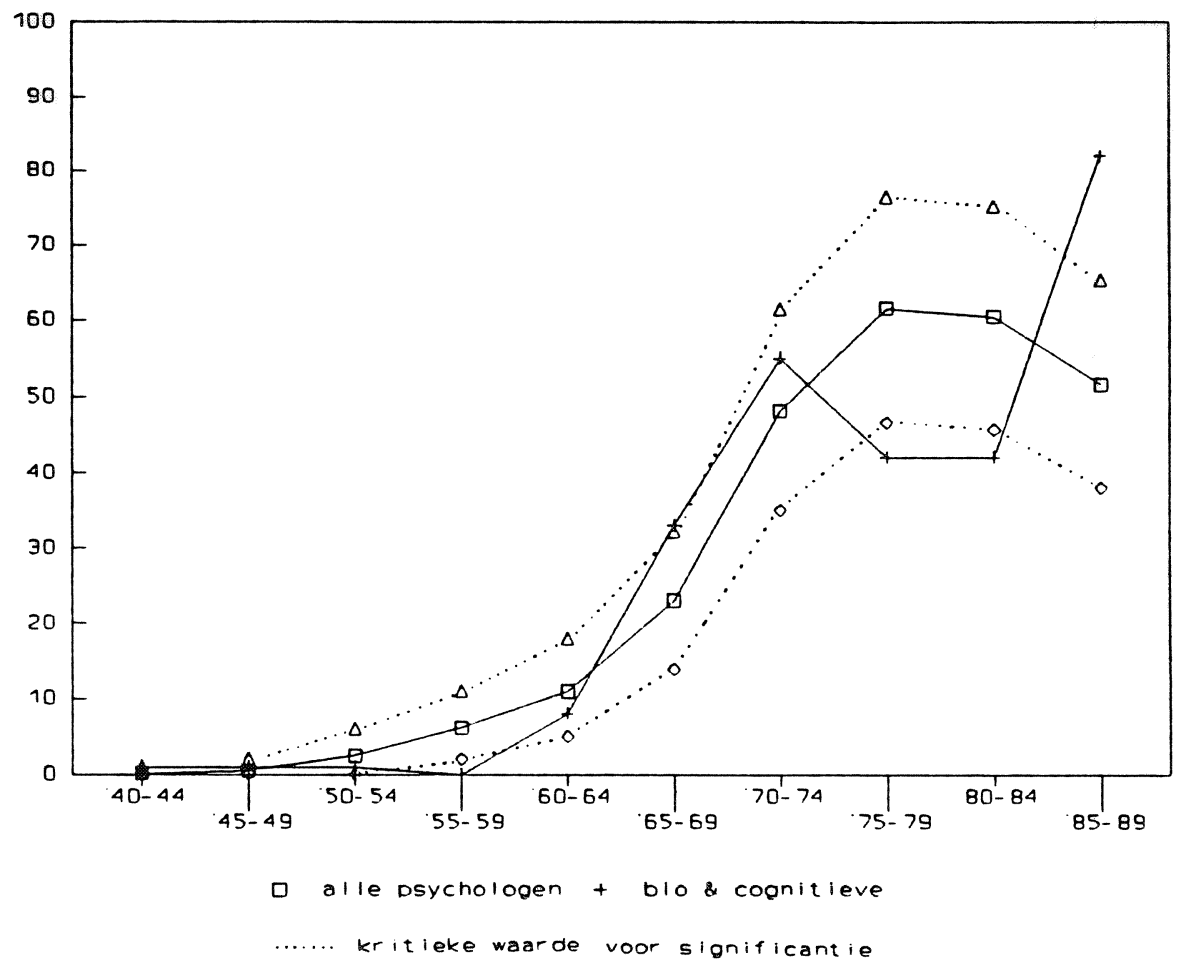

Figuur 5.1 laat zien dat ook op basis van één bestand reeds een indruk verkregen kan worden van de dynamische ontwikkelingen binnen de psychologie. Het geeft een beeld van de opbouw van het NIP-ledenbestand naar het jaar van afstuderen. Voor de afstudeerjaren 1975 tot 1984 is het aantal bio- en cognitieve psychologen in het NIP-bestand significant lager dan gemiddeld. $\mathrm{Na}$ 1984 is dit aantal juist significant hoger. De dynamiek in figuur 5.1 kan vergeleken worden met figuur 2.1. Hieruit blijkt dat deze inzinking van functieleer ook in de uitstroom terug te vinden is, hoewel hij daar niet significant bleek te zijn. 


\section{PSYCHOLOGIE IN DE VERENIGDE STATEN}

\subsection{Inleiding}

Naast de mogelijkheid om voorspellingen te maken van de arbeidsmarkt voor bio- en cognitieve psychologen op basis van data met betrekking tot de ontwikkelingen binnen psychologie in Nederland, kan mogelijk ook informatie worden ontleend aan de ontwikkelingen in andere landen. Voor voorspellingsdoeleinden kan zo'n vergelijking tussen landen het best plaatsvinden als het vergelijkingsland op psychologiegebied enigszins vooruitloopt in ontwikkeling op Nederland. Een voor-de-hand-liggende keuze is derhalve de Verenigde Staten. In dit hoofdstuk wordt daarom gekeken naar de beschikbare informatie over de arbeidsmarkt van psychologen in de Verenigde Staten. Twee bronnen zijn hiervoor relevant. In paragraaf 6.2 wordt de arbeidsmarktinformatie van het Bureau of Labor Statistics (BLS) besproken en in paragraaf 6.3 komt de Census of Psychological Personnel van de American Psychological Association (APA) aan de orde. De gegevens van de APA worden vergeleken met de informatie uit het NIPledenbestand.

\subsection{Bureau of Labor Satistics}

Het Bureau of Labor Statistics (BLS) is een onderdeel van het US Department of Labor en heeft als doel informatie te verschaffen over de ontwikkelingen op de arbeidsmarkt om daarmee de beroepskeuze te ondersteunen. Daartoe maakt het BLS tweejaarlijks een voorspelling van de werkgelegenheid per beroep, die gepubliceerd wordt in het Occupational Outlook Handbook. Het BLS geeft geen informatie per opleidingstype. Als het BLS dus spreekt over psychologen, gaat het over mensen met het beroep psycholoog en niet de opleiding psychologie.

Tabel 6.1 geeft een globaal overzicht van de karakteristieken van de beroepsgroep psychologen in de VS. Van 1986 tot 2000 stijgt de werkgelegenheid voor psychologen met 34\%. Dit is hoog vergeleken met andere academische beroepen in de VS. De vervangingsvraag is laag vergeleken met andere beroepen. Verder werkt een voor Amerikaanse begrippen groot deel van de psychologen part-time.

Tabel 6.2 en 6.3 geven aan waar de Amerikaanse psychologen werkzaam zijn. Tabel 6.2 bevat de verdeling naar bedrijfstak en tabel 6.3 de verdeling naar beroepsactiviteit. Het percentage psychologen in de VS dat werkzaam is in het onderwijs komt redelijk overeen met het percentage WO Sociaal-Cultureel in de AKT dat in het onderwijs werkzaam is $(36 \%)$. In Nederland is (volgens NIP-gegevens) een veel groter deel van de psychologen werkzaam in de gezondheidszorg en maatschappelijke dienstverlening (respectievelijk $28 \%$ en $47 \%$ ). Daarentegen werken in de VS veel meer psychologen bij de overheid. Deze verschillen kunnen voor een deel veroorzaakt zijn door institutionele verschillen tussen Nederland en de VS. 
Tabel 6.1. Werkgelegenheid van psychologen in de VS, 1986 en voorspelling 2000, en enkele werkkarakteristieken

aantal werkenden

1986

2000

werkgelegenheidsgroei

1986-2000

in \%

werkkarakteristieken in \%

verlooppercentage (jaarlijks)

parttime
110.000

148.000

37.000

34,0

5,0

23,5

Bron: BLS (1988)

Tabel 6.2. Werkgelegenheid psychologen in VS, 1986 naar bedrijfstak

$\%$

education, public and private

34,2

hospitals, public and private

11,5

individual and miscellaneous social services

9,6

outpatient care facilities

9,3

state government, except education and hospitals

8,0

federal government, except postal service

5,6

offices of other health practitioners

5,0

Bron: BLS (1988)

Tabel 6.3. Werkgelegenheid psychologen in de VS naar beroepsactiviteit in 1981

$\%$

consulting/professional services

teaching

28

management/administration

15

research/development/design

other

Bron: BLS (1984)

De hierboven gepresenteerde informatie van het BLS wordt elke twee jaar herzien. Op grond van meerdere BLS-publicaties zou een tijdreeks gevormd kunnen worden die niet alleen de actuele situatie, maar ook de recente ontwikkelingen daarin kan verduidelijken. 


\subsection{American Psychological Association}

De American Psychological Association (APA) is een beroepsvereniging van Amerikaanse psychologen, vergelijkbaar met het NIP in Nederland. Om meer zicht te krijgen op de arbeidsmarktpositie van haar leden begon de APA in 1971 met jaarlijkse enquêtes onder psychologie-afdelingen en afgestudeerde 'doctoral' psychologen afkomstig van meer dan 450 'university programs'15. Vanaf 1975 werden de betreffende psychologen zelf rechtstreeks benaderd met een groter aantal vragen. De verslagen van deze 'Doctorate Employment Surveys' werden elk jaar in de American Psychologist gepubliceerd. Overigens worden niet alleen APAleden hiervoor benaderd, maar ook niet-leden. Daarnaast hield APA sinds 1972 periodiek eenmaal per drie jaar - het zogenaamde 'Human Resources Survey' onder haar leden. Ook de verslagen hiervan verschenen in de American Psychologist. De laatste survey die gepubliceerd werd in de American Psychologist stamt uit 1983 (Stapp, Tucker en VandenBos, 1985). Het is niet duidelijk of deze surveys nog steeds gehouden worden.

De Census of Psychological Personnel over 1983 bevat, behalve de informatie die hier gebruikt wordt, informatie over de primaire, secondaire en tertiaire 'employment setting' en de aard van de uitgeoefende aktiviteiten. Deze tabellen zijn niet uitgesplitst naar afstudeerrichting. Daarnaast vermeldt men sexe, etniciteit, leeftijd, jaar waarin de hoogste graad werd behaald en het al dan niet lid zijn van de APA. De meeste informatie wordt uitgesplitst naar personen betrokken bij 'research activities', 'educational activities' en 'health/mental health services'. In deze paragraaf wordt gekeken naar de verdeling van Amerikaanse psychologen over de 'major fields'. Deze spreiding naar werkveld wordt vergeleken met de Nederlandse situatie zoals die uit het NIPledenbestand naar voren komt.

Zoals reeds eerder werd vermeld, maakt de APA gebruik van gegevens van zowel leden als nietleden. Het Nederlandse NIP-bestand is daar niet helemaal vergelijkbaar mee, omdat in dit bestand alleen de situatie van de leden is opgenomen. Bepaalde takken van de psychologie zijn oververtegenwoordigd binnen het NIP, zoals in hoofdstuk 5 al opgemerkt werd. Een tweede reden waarom de twee bronnen niet helemaal vergelijkbaar zijn, is dat in het Amerikaanse survey de respondenten ingedeeld zijn naar het veld waarin ze op dat moment werkzaam waren, terwijl in het Nederlandse bestand ingedeeld is naar de richting waarin men afgestudeerd is.

Zoals gezegd, kan een vergelijking tussen de vakdisciplines van de Amerikaanse en Nederlandse psychologen mogelijk een beeld geven van de ontwikkelingen die hier te verwachten zijn, onder de veronderstelling dat de Amerikaanse situatie vooruitloopt op de situatie in Nederland. Uiteraard moeten conclusies op dit punt met grote voorzichtigheid worden getrokken, aangezien ook institutionele aspecten die specifiek voor een land gelden invloed kunnen hebben op de spreiding van psychologen over de verschillende vakrichtingen.

15. Jonkergouw (1975a, 1975b, 1976) beschrijft deze ontwikkelingen bij de APA uitvoerig. 
Om de vergelijking toe te spitsen op de Maastrichtse psychologierichtingen zijn de richtingen wederom verdeeld in een groep die verwant is aan bio- en cognitieve psychologie en een groep die hieraan niet verwant is. Binnen deze twee groepen is een verdere verdeling gemaakt tussen de richtingen, die zowel in Nederland als in de VS voorkomen, en de vakrichtingen, die of alleen in de VS of alleen in Nederland voorkomen.

Tabel 6.4. Vakdiscipline van Amerikaanse de Nederlands psychologen

\begin{tabular}{|c|c|c|c|c|c|c|}
\hline $\begin{array}{l}\text { current major field } \\
\text { APA }\end{array}$ & $\%$ & $N$ & $\begin{array}{l}\text { afstudeerrichting } \\
\text { NIP }\end{array}$ & $\%$ & $\mathbf{N}$ & $\begin{array}{l}\text { significant } \\
\text { verschil }\end{array}$ \\
\hline
\end{tabular}

\begin{tabular}{|c|c|c|c|c|c|c|}
\hline $\begin{array}{l}\text { comparative } \\
\text { experimental } \\
\text { physiological } \\
\text { systems/history/methods }\end{array}$ & $\begin{array}{l}0,2 \\
2,4 \\
1,1 \\
0,3\end{array}$ & $\begin{array}{r}176 \\
1.927 \\
846 \\
208\end{array}$ & $\begin{array}{l}\text { vergelijkende } \\
\text { experimentele } \\
\text { fysiologie } \\
\text { methodenleer }\end{array}$ & $\begin{array}{l}0,0 \\
0,2 \\
0,1 \\
0,6\end{array}$ & $\begin{array}{r}1 \\
8 \\
7 \\
33\end{array}$ & $\begin{array}{l}+ \\
+ \\
+ \\
-\end{array}$ \\
\hline $\begin{array}{l}\text { cognitive } \\
\text { psychometrics } \\
\text { psychopharmacology } \\
\text { quantitative } \\
\text { subtotaal }\end{array}$ & $\begin{array}{l}1,0 \\
1,1 \\
0,3 \\
0,5\end{array}$ & $\begin{array}{l}790 \\
918 \\
272 \\
420\end{array}$ & $\begin{array}{l}\text { neuro- en revps } \\
\text { functieleer } \\
\text { gerontologie } \\
\text { psychonomie } \\
\text { gedragsleer } \\
\text { medische } \\
\text { subtotaal }\end{array}$ & $\begin{array}{l}0,2 \\
2,1 \\
1,1 \\
0,2 \\
0,7 \\
0,0 \\
5,2\end{array}$ & $\begin{array}{r}11 \\
104 \\
54 \\
11 \\
36 \\
1 \\
266\end{array}$ & + \\
\hline \multicolumn{7}{|c|}{ afstudeerrichtingen die niet verwant zijn aan bio- en cognitieve psychologie } \\
\hline $\begin{array}{l}\text { clinical } \\
\text { developmental } \\
\text { educational } \\
\text { general } \\
\text { school } \\
\text { social } \\
\text { (systems/history/methods }\end{array}$ & $\begin{array}{r}38,0 \\
3,5 \\
6,3 \\
1,7 \\
13,1 \\
2,3 \\
0,3\end{array}$ & $\begin{array}{r}30.460 \\
2.754 \\
5.044 \\
1.365 \\
10.480 \\
1.816 \\
2081\end{array}$ & $\begin{array}{l}\text { klinische } \\
\text { ontwikkelings } \\
\text { onderwijskunde } \\
\text { alg. wijg. theor. } \\
\text { schoolpsych. } \\
\text { sociale } \\
\text { historische }\end{array}$ & $\begin{array}{r}49,9 \\
15,0 \\
1,1 \\
0,3 \\
0,4 \\
5,2 \\
0,0\end{array}$ & $\begin{array}{r}2.501 \\
753 \\
57 \\
16 \\
18 \\
262 \\
1\end{array}$ & $\begin{array}{l}- \\
- \\
+ \\
+ \\
+ \\
+ \\
+\end{array}$ \\
\hline $\begin{array}{l}\text { community } \\
\text { couseling } \\
\text { personality }\end{array}$ & $\begin{array}{r}1,4 \\
11,7 \\
0,6\end{array}$ & $\begin{array}{r}1.120 \\
9.336 \\
514\end{array}$ & $\begin{array}{l}\text { persoonlijkheidsleer } \\
\text { differentiële } \\
\text { kinder- en jeugd } \\
\text { arbeids- en org. } \\
\text { cultuurpsych. } \\
\text { pedologie } \\
\text { beroepskeuze } \\
\text { conflictuologie } \\
\text { economische } \\
\text { andragologie } \\
\text { subtotaal }\end{array}$ & $\begin{array}{r}5,6 \\
0,7 \\
5,8 \\
7,2 \\
0,3 \\
0,1 \\
0,2 \\
0,0 \\
0,0 \\
0,0 \\
90,2\end{array}$ & $\begin{array}{r}281 \\
35 \\
292 \\
363 \\
16 \\
3 \\
11 \\
2 \\
2 \\
1 \\
4.614\end{array}$ & - \\
\hline \multicolumn{7}{|l|}{ overig } \\
\hline $\begin{array}{l}\text { engineering } \\
\text { industrial/organizational } \\
\text { psycholinguistics } \\
\text { other, in psychology } \\
\text { other, not in psychology } \\
\text { not specified } \\
\text { total }\end{array}$ & $\begin{array}{r}1,0 \\
4,7 \\
0,2 \\
3,3 \\
3,6 \\
1,6 \\
100\end{array}$ & $\begin{array}{r}837 \\
3.782 \\
157 \\
2.659 \\
2.910 \\
1.283 \\
80.085\end{array}$ & $\begin{array}{l}\text { anders dan psyologie } \\
\text { overig } \\
\text { totaal }\end{array}$ & $\begin{array}{l}0,2 \\
4,6 \\
100\end{array}$ & $\begin{array}{r}10 \\
228 \\
5.118\end{array}$ & \\
\hline
\end{tabular}

Tabel 6.4 geeft de resultaten van de vergelijking tussen Nederland en de Verenigde Staten voor de totale psychologenpopulatie. De APA-categorie 'systems/history/methods' past zowel bij de 
aan bio- en cognitieve psychologie verwante methodenleer, als bij de niet verwante historische psychologie. In de tabel is deze richting daarom twee maal opgenomen. Omdat in Nederland deze groep vooral bestaat uit de afgestudeerden in de richting methodenleer is deze categorie bij de totalen alleen meegenomen bij de aan bio- en cognitieve psychologie verwante groep.

Uit de tabel blijkt dat de aan bio- en cognitieve psychologie verwante richtingen in Nederland significant kleiner zijn dan in de Verenigde Staten. De enige uitzondering binnen de verwante richtingen is methodenleer, dat in Nederland significant groter is dan in de Verenigde Staten. Er is daarentegen een groot verschil met betrekking tot experimentele psychologie, terwijl men verder in de VS een relatief grote groep cognitieve psychologen kent. Zelfs als functieleer hier tegenover geplaatst wordt is er een tekort aan Nederlandse zijde. Opgemerkt moet echter worden dat het absoluut gezien om kleine aantallen gaat. Als de verhoudingen in de VS geprojecteerd worden op Nederland zouden hier 113 extra experimentele psychologen kunnen werken, en 51 cognitieve psychologen en staan hier in Nederland 104 functieleerpsychologen tegenover. Het totale 'tekort' in Nederland voor deze drie richtingen betreft dus absoluut gezien 60 personen.

Bij de niet-verwante richtingen is het beeld minder eenduidig. De Nederlandse richting ontwikkelingspsychologie is veel groter dan developmental psychology in de VS. Ook klinische psychologie is hier groter dan clinical psychology in de VS. Bij de schoolpsychologie is de Amerikaanse richting echter juist de grootste. Het algemene beeld is echter overduidelijk dat de niet-verwante richtingen in Nederland belangrijk groter zijn dan in de Verenigde Staten.

Tabel 6.5 bevat een vergelijking tussen Nederland en de VS met betrekking tot psychologen die werkzaam zijn in de research. Omdat de aantallen in de categorie research erg klein zijn levert een vergelijking tussen de VS en Nederland voor deze vakdicipline weinig op. De gevonden verschillen tussen de Amerikaanse en de Nederlandse situatie zijn alle niet significant. Het opmerkelijkste verschil tussen Nederland en de VS is niet de verdeling over de richtingen, maar het verschil in het percentage psychologen dat betrokken is bij research. In de VS is maar liefst $42 \%$ van de psychologen bij research betrokken, terwijl dit in Nederland, volgens het NIPledenbestand, nog geen $1 \%$ is. Het is niet helemaal duidelijk waardoor dit verschil veroorzaakt wordt. Waarschijnlijk zal de definitie van het betrokken zijn bij research in de twee bestanden verschillen. Het aantal NIP-leden in het werkveld wetenschappelijk onderzoek is onwaarschijnlijk klein. Het lijkt daarom zinvol om voor Nederland de groep 'onderzoek' te definiëren op grond van de standaard bedrijfsindeling.

Uit een vergelijking tussen tabel 6.4 en 6.5 blijkt dat in de Verenigde Staten het percentage in de research werkende respondenten bij de groep aan bio- en cognitieve psychologie verwante richtingen beduidend hoger ligt dan bij de groep niet-verwante richtingen. Rond de $90 \%$ van de respondenten uit de verwante groep is betrokken bij research, terwijl dit in de niet-verwante groep slechts $40 \%$ is. 
Tabel 6.5 Amerikaanse en Nederlands psychologen die betrokken zijn bij onderzoeksactiviteiten naar vakdiscipline

\begin{tabular}{|c|c|c|c|c|c|c|}
\hline $\begin{array}{l}\text { current major field } \\
\text { APA }\end{array}$ & $\%$ & $\mathrm{~N}$ & $\begin{array}{l}\text { afstudeerrichting } \\
\text { NIP }\end{array}$ & $\%$ & $\mathrm{~N}$ & $\begin{array}{l}\text { significante } \\
\text { verschil }\end{array}$ \\
\hline
\end{tabular}

afstudeerrichtingen die verwant zijn aan bio- en cognitieve psychologie

$\begin{array}{lrrlrr}\text { comparative } & 0,4 & 148 & \text { vergelijkende } & 0,0 & 0 \\ \text { experimental } & 4,7 & 1.598 & \text { experimentele } & 0,0 & 0 \\ \text { physiological } & 2,0 & 693 & \text { fysiologie } & 0,0 & 0 \\ \text { systems/history/methods } & 0,4 & 137 & \text { methodenleer } & 0,0 & 0 \\ & & & & & \\ \text { cognitive } & 1,9 & 657 & \text { neuro- en revps } & 3,4 & 1 \\ \text { psychometrics } & 1,1 & 386 & \text { functieleer } & 10,3 & 3 \\ \text { psychopharmacology } & 0,7 & 247 & \text { gerontologie } & 0,0 & 0 \\ \text { quantitative } & 1,0 & 354 & \text { psychonomie } & 0,0 & 0 \\ & & & \text { gedragsleer } & 0,0 & 0 \\ & & & \text { medische } & 0,0 & 0 \\ \text { subtotaal } & 12,4 & 4.220 & \text { subtotal } & 13,8 & 4\end{array}$

afstudeerrichtingen die niet verwant zijn aan bio- en cognitieve psychologie

\begin{tabular}{|c|c|c|c|c|}
\hline $\begin{array}{l}\text { clinical } \\
\text { developmental } \\
\text { educational } \\
\text { general } \\
\text { school } \\
\text { social } \\
\text { (systems/history/methods }\end{array}$ & $\begin{array}{r}31,0 \\
5,5 \\
7,3 \\
1,5 \\
7,7 \\
4,2 \\
0,4\end{array}$ & $\begin{array}{r}10.545 \\
1.888 \\
2.470 \\
500 \\
2.603 \\
1.425 \\
137\end{array}$ & $\begin{array}{l}\text { klinische } \\
\text { ontwikkelings } \\
\text { onderwijskunde } \\
\text { alg. wijg. theor. } \\
\text { schoolpsych. } \\
\text { sociale } \\
\text { historische }\end{array}$ & $\begin{array}{r}41,4 \\
10,3 \\
0,0 \\
0,0 \\
0,0 \\
3,4 \\
0,0\end{array}$ \\
\hline $\begin{array}{l}\text { community } \\
\text { couseling } \\
\text { personality }\end{array}$ & $\begin{array}{r}1,4 \\
10,1 \\
1,0\end{array}$ & $\begin{array}{r}490 \\
3.451 \\
351\end{array}$ & $\begin{array}{l}\text { persoonlijkheidsleer } \\
\text { differentiële } \\
\text { kinder- en jeugd } \\
\text { arbeids- en org. } \\
\text { cultuurpsych. } \\
\text { pedologie } \\
\text { beroepskeuze } \\
\text { conflictuologie } \\
\text { economische } \\
\text { andragologie } \\
\text { subtotaal }\end{array}$ & $\begin{array}{l}3,4 \\
0,0 \\
0,0 \\
6,9 \\
0,0 \\
0,0 \\
0,0 \\
0,0 \\
0,0 \\
0,0 \\
65,5\end{array}$ \\
\hline \multicolumn{5}{|l|}{ overig } \\
\hline $\begin{array}{l}\text { engineering } \\
\text { industrial/organizational } \\
\text { psycholinguistics } \\
\text { other, in psychology } \\
\text { other, not in psychology } \\
\text { not specified } \\
\text { total }\end{array}$ & $\begin{array}{r}1,8 \\
6,7 \\
0,4 \\
4,7 \\
3,4 \\
0,8 \\
100\end{array}$ & $\begin{array}{r}611 \\
2.284 \\
142 \\
1.613 \\
1.152 \\
277 \\
34.022\end{array}$ & $\begin{array}{l}\text { anders dan psycholo } \\
\text { overig } \\
\text { totaal }\end{array}$ & $\begin{array}{l}\text { ie } 0,0 \\
20,7 \\
100\end{array}$ \\
\hline
\end{tabular}


$-38-$

Tabel 6.6. Amerikaanse de Nederlands psychologen betrokken bij onderwijsactiviteiten over de richtingen

\begin{tabular}{|c|c|c|c|c|c|c|}
\hline $\begin{array}{l}\text { current major field } \\
\text { APA }\end{array}$ & $\%$ & $\mathrm{~N}$ & $\begin{array}{l}\text { afstudeerrichting } \\
\text { (NIP) }\end{array}$ & $\%$ & $\mathbf{N}$ & $\begin{array}{l}\text { significante } \\
\text { verschillen }\end{array}$ \\
\hline
\end{tabular}

\section{afstudeerrichtingen die verwant zijn aan bio- en cognitieve psychologie}

\begin{tabular}{|c|c|c|c|c|c|c|}
\hline $\begin{array}{l}\text { comparative } \\
\text { experimental } \\
\text { physiological } \\
\text { systems/history/methods }\end{array}$ & $\begin{array}{l}0,3 \\
2,9 \\
1,3 \\
0,3\end{array}$ & $\begin{array}{r}159 \\
1.536 \\
696 \\
167\end{array}$ & $\begin{array}{l}\text { vergelijkende } \\
\text { experimentele } \\
\text { fysiologie } \\
\text { methodenleer }\end{array}$ & $\begin{array}{l}0,0 \\
0,0 \\
0,0 \\
0,3\end{array}$ & $\begin{array}{l}0 \\
0 \\
0 \\
2\end{array}$ & $\begin{array}{l}+ \\
+ \\
+\end{array}$ \\
\hline $\begin{array}{l}\text { cognitive } \\
\text { psychometrics } \\
\text { psychopharmacology } \\
\text { quantitative } \\
\text { subtotaal }\end{array}$ & $\begin{array}{l}1,2 \\
1,1 \\
0,4 \\
0,6 \\
8,0\end{array}$ & $\begin{array}{l}646 \\
567 \\
192 \\
323\end{array}$ & $\begin{array}{l}\text { neuro- en revps } \\
\text { functieleer } \\
\text { gerontologie } \\
\text { psychonomie } \\
\text { gedragsleer } \\
\text { medische } \\
\text { subtotaal }\end{array}$ & $\begin{array}{l}0,2 \\
1,9 \\
0,3 \\
0,2 \\
1,4 \\
0,0 \\
4,3\end{array}$ & $\begin{array}{r}1 \\
11 \\
2 \\
1 \\
8 \\
0 \\
25\end{array}$ & + \\
\hline \multicolumn{7}{|c|}{ afstudeerrichtingen die niet verwant zijn aan bio-en cognitieve psychologie } \\
\hline $\begin{array}{l}\text { clinical } \\
\text { developmental } \\
\text { educational } \\
\text { general } \\
\text { school } \\
\text { social } \\
\text { (systems/history/methods }\end{array}$ & $\begin{array}{r}32,9 \\
4,2 \\
8,3 \\
2,2 \\
16,2 \\
2,7 \\
0,3\end{array}$ & $\begin{array}{r}17.683 \\
2.273 \\
4.466 \\
1.162 \\
8.721 \\
1.457 \\
167\end{array}$ & $\begin{array}{l}\text { klinische } \\
\text { ontwikkelings } \\
\text { onderwijskunde } \\
\text { alg. wijg. theor. } \\
\text { schoolpsych. } \\
\text { sociale } \\
\text { historische }\end{array}$ & $\begin{array}{r}22,0 \\
30,1 \\
6,4 \\
0,3 \\
2,6 \\
4,1 \\
0,0\end{array}$ & $\begin{array}{r}128 \\
175 \\
37 \\
2 \\
15 \\
24 \\
0\end{array}$ & $\begin{array}{l}+ \\
- \\
+ \\
+ \\
+\end{array}$ \\
\hline $\begin{array}{l}\text { community } \\
\text { couseling } \\
\text { personality }\end{array}$ & $\begin{array}{r}1,3 \\
11,7 \\
0,8\end{array}$ & $\begin{array}{r}676 \\
6.259 \\
406\end{array}$ & $\begin{array}{l}\text { persoonlijkheidsleer } \\
\text { differentiële } \\
\text { kinder- en jeugd } \\
\text { arbeids- en org. } \\
\text { cultuurpsych. } \\
\text { pedologie } \\
\text { beroepskeuze } \\
\text { conflictuologie } \\
\text { economische } \\
\text { andragologie } \\
\text { subtotaal }\end{array}$ & $\begin{array}{r}4,8 \\
0,9 \\
11,3 \\
7,6 \\
0,2 \\
0,0 \\
1,2 \\
0,0 \\
0,2 \\
0,0 \\
91,6\end{array}$ & $\begin{array}{r}28 \\
5 \\
66 \\
44 \\
1 \\
0 \\
7 \\
0 \\
1 \\
0 \\
533\end{array}$ & - \\
\hline \multicolumn{7}{|l|}{ overig } \\
\hline $\begin{array}{l}\text { engineering } \\
\text { industrial/organizational } \\
\text { psycholinguistics } \\
\text { other, in psychology } \\
\text { other, not in psychology } \\
\text { not specified } \\
\text { total }\end{array}$ & $\begin{array}{r}0,5 \\
3,9 \\
0,2 \\
3,3 \\
2,7 \\
1,0 \\
100\end{array}$ & $\begin{array}{r}278 \\
2.085 \\
133 \\
1.785 \\
1.465 \\
534 \\
53.669\end{array}$ & $\begin{array}{l}\text { anders dan psychologie } \\
\text { overig } \\
\text { totaal }\end{array}$ & $\begin{array}{l}0,2 \\
2,6 \\
100\end{array}$ & $\begin{array}{r}1 \\
15 \\
582\end{array}$ & \\
\hline
\end{tabular}

Tabel 6.6 geeft van de VS en Nederland een beeld van de vakdiscrepanties van degenen die werkzaam zijn in het onderwijs. Ook hier is de totale betrokkenheid bij het onderwijs in de VS veel groter dan in Nederland. In de VS zijn de bij het onderwijs betrokken psychologen vrijwel evenredig uit alle vakrichtingen afkomstig. Alleen klinisch psychologen zijn daarbij minder vertegenwoordigd.

In de vergelijking tussen Nederland en de VS zijn de aan bio- en cognitieve psychologie 
verwante richtingen relatief weinig betrokken bij het onderwijs. Dit vormt echter een afspiegeling van het in vergelijking met de VS relatieve tekort aan psychologen uit deze richtingen in het algemeen. Opvallend is echter dat, hoewel klinische psychologie in Nederland goed vertegenwoordigd is, de relative bijdrage van deze richting aan het onderwijs nog lager is dan in de VS. Kennelijk nemen de niet-klinische richtingen in Nederland relatief gezien een groot aandeel van het onderwijs voor hun rekening.

De survey van de APA geeft, te zamen met de ledeninformatie van het NIP, een goed beeld van de verschillen van de diverse richtingen tussen Nederland en de Verenigde Staten. Voor het opstellen van een prognose van de arbeidsmarktsituatie voor bio- en cognitieve psychologen in Nederland is deze informatie niet direct inpasbaar, maar het zou zeer interessant zijn om de arbeidsmarktconsequenties door te rekenen voor de hypothetische situatie dat de Nederlandse situatie toegroeit naar de situatie zoals die momenteel waarneembaar in de VS. Om dit op een zinvolle wijze te kunnen doen zal echter wel, net als bij het gebruik van de NIPledenadministratie is gedaan, een duidelijke koppeling gemaakt moeten worden tussen de Amerikaanse en de Nederlandse vakdiscrepanties. 


\section{MOGELIJKHEDEN VOOR ARBEIDSMARKTPROGNOSES}

In de voorgaande hoofdstukken is een overzicht gegeven van de informatiebronnen die relevant zijn voor een onderzoek naar de toekomstige arbeidsmarktperspectieven van bio- en cognitieve psychologen. In dit slothoofdstuk worden deze mogelijke informatiebronnen nogmaals op een rij gezet en worden vervolgens de mogelijkheden geschetst om te komen tot arbeidsmarktprognoses.

Zoals in de inleiding werd beschreven zijn er twee mogelijke invalshoeken om de perspectieven van een nieuwe studierichting te benaderen. De eerste benadering sluit aan bij de traditionele 'manpower forecasting' benadering. Gekeken wordt hoe vraag en aanbod in het betreffende vakgebied zich ontwikkelen. Omdat het onderzoek zich op de positie van nieuwkomers op de arbeidsmarkt zal richten, wordt het aanbod bepaald door het aantal toekomstige afstudeerders en de vraag door uitbreidingsvraag en de vervangingsvraag. De confrontatie van het voorspelde aanbod met de voorspelde vraag geeft een indicatie van de verwachte spanning op de arbeidsmarkt. Voor deze benadering moeten prognoses gemaakt worden van de aantallen studenten die afstuderen in de betreffende richtingen en van de ontwikkelingen in de voor de studierichting bio- en cognitieve psychologie relevante beroepen en bedrijfssectoren.

De tweede invalshoek richt zich op de aanbodkant. Gekeken wordt of een studierichting bio- en cognitieve psychologie een bepaalde groep studenten betere kansen op de arbeidsmarkt kan geven dan de studierichtingen die thans deze studenten opleiden. Hiervoor dient gekeken te worden naar de achtergrondkenmerken van de doelgroep van de nieuwe studierichting en moet een vergelijking gemaakt worden met studierichtingen die dezelfde doelgroep hebben. Aan de arbeidsmarktkant is bij deze invalshoek niet primair de vraag binnen het specifieke beroepsdomein van belang. Het gaat hierbij om de algemene arbeidsmarktpositie van de afgestudeerden, dus ook van hen die buiten de typische psychologieberoepen zullen gaan werken. Voor deze benadering moet dus onderzocht worden welke studierichtingen qua achtergrondkenmerken van de studenten vergelijkbaar zijn met bio- en cognitieve psychologie, en vervolgens moeten er prognoses gemaakt worden van de algemene arbeidsmarktpositie van deze studierichtingen zodat de relatieve positie van bio- en cognitieve psychologie bepaald kan worden.

Om na te gaan welke mogelijkheden er zijn om te komen tot arbeidsmarktprognoses voor bioen cognitieve psychologie vanuit deze twee benaderingen, zijn in dit rapport de beschikbare informatiebronnen besproken. Kort samengevat zijn de volgende mogelijke databronnen met betrekking tot de arbeidsmarktsituatie van bio- en cognitieve psychologen aan de orde gekomen:

- In hoofdstuk 2 werden de resultaten van enkele bestaande onderzoeken met betrekking tot de arbeidsmarkt van psychologen besproken. De meeste gegevens zijn echter verouderd en onvoldoende toegespitst op bio- en cognitieve psychologie. Zij kunnen hoogstens gebruikt worden om nieuw te genereren informatie in een (historisch) kader te plaatsen. Van belang zijn echter wel de gegevens van Holtzer (1984) over de uitstroom bij psychologie per 
afstudeerrichting.

- In hoofdstuk 3 werden de gegevens over de aanbodkant van de arbeidsmarkt besproken. De referentie- en verdeelramingen van het Ministerie van Onderwijs en Wetenschappen bieden een goed startpunt voor een aanbodprognose, maar deze prognoses zullen wel verbijzonderd moeten worden naar afstudeerrichting. Hierbij zal gebruik moeten worden gemaakt van recente uitstroomgegevens voor de afstudeerrichtingen die verwant zijn aan bio- en cognitieve psychologie. Verder zijn er geen goede gegevens voorhanden over de (verwachte) achtergrond van de psychologiestudenten. Hoewel dit soort informatie voor een vergelijking van de arbeidsmarktperspectieven belangrijk is, zal volstaan moeten worden met de veronderstelling dat de instroom bij bio- en cognitieve psychologie vergelijkbaar is met de instroom in de sociale wetenschappen in het algemeen.

- De Enquête Beroepsbevolking (EBB) en de Arbeidskrachtentelling geven een goed overzicht van de totale Nederlandse arbeidsmarktsituatie. Bovendien zijn de indelingen waarop de enquêtes zijn gebaseerd ook gehanteerd bij de ROA-prognoses naar opleiding en beroep in 1994. Gekeken zou kunnen worden naar de specifieke beroepsklassen waarin bio- en cognitieve psychologen, vergeleken met andere psychologen en sociale wetenschappers, terecht zullen komen. Deze verschillen kunnen vervolgens gerelateerd worden aan de door het ROA voorspelde perspectieven naar beroepsklasse. De EBB en de AKT zijn echter niet gedetailleerd genoeg om direct hiervoor gebruikt te kunnen worden. Meer specifieke gegevens zullen nodig zijn om de relatie tussen de verwachte markt voor bio- en cognitieve psychologen en de ROA-prognoses te kunnen leggen.

- Van de ledenadministraties van psychologieverenigingen blijkt alleen het NIP-ledenbestand, dat ook informatie levert over de gevolgde afstudeerrichting, goed bruikbaar voor een onderzoek naar de arbeidsmarktpositie van bio- en cognitieve psychologen. Het bestand geeft uitgebreide informatie over het werkveld en de bedrijfssector van de aangesloten psychologen. Indien gebruik gemaakt kan worden van het ledenbestand op twee verschillende momenten, kan het bestand goed gebruikt kunnen worden voor het opstellen van zowel een prognose van de uitbreidingsvraag, als van de vervangingsvraag binnen de verschillende bedrijfstakken waar psychologen werkzaam zijn. Verder kan onderzocht worden in welke mate bio- en cognitieve psychologen werkzaam zijn in deze bedrijfstakken. De informatie uit het NIP-bestand kan ook gebruikt worden om specifiek voor bio- en cognitieve psychologie een band te leggen met de ROA-prognoses per beroep.

- Ten slotte bieden de gegevens van het BLS en de APA een beeld van de situatie in de Verenigde Staten. De informatie van het BLS kan inzicht geven in de ontwikkelingen in de VS, terwijl de informatie van de APA gebruikt kan worden om de Nederlandse arbeidsmarktsituatie van psychologen te vergelijken met de Amerikaanse situatie.

De beschikbare data maakt het opstellen van prognoses van de arbeidsmarktsituatie van bio- en cognitieve psychologen vanuit beide theoretische invalshoeken mogelijk. Hierbij zullen echter 
wel enkele beperkingen aan het onderzoek opgelegd moeten worden.

Ten eerste kan een vergelijking opgesteld worden van vraag en aanbod op het vakgebied bio- en cognitieve psychologie. Aanbodprognoses kunnen gebaseerd worden op de referentie- en verdeelramingen die vervolgens, met behulp van informatie die bij de faculteiten verzameld moet worden, verder opgesplitst zullen moeten worden naar afstudeerrichting. Vraagprognoses kunnen gebaseerd worden op het NIP-ledenbestand. Met behulp van de CPB- en ROA-prognoses per bedrijfstak kunnen de ontwikkelingen binnen de psychologie doorgetrokken worden tot 1998, zodat een voorspelling van de uitbreidingsvraag verkregen wordt. Een vergelijking van de leeftijdsopbouw tussen de twee NIP-bestanden (1989 en een recente versie) biedt de mogelijkheid om de vervangingsvraag in die periode te berekenen en mede met behulp daarvan prognoses voor de toekomstige vervangingsvraag te maken. Samen leveren deze drie arbeidsmarktstromen - aanbod, vervangingsvraag en uitbreidingsvraag - een prognose op van de te verwachten overschotten of tekorten aan bio- en cognitieve psychologen. Gezien de kleine aantallen personen op de markt voor bio- en cognitieve psychologie zal een confrontatie tussen vraag en aanbod echter met grote voorzichtigheid bekeken moeten worden. De verwachte arbeidsmarktontwikkelingen zijn vanuit dit perspectief waarschijnlijk belangrijker dan de precieze omvang van het verschil tussen vraag en aanbod. Als aanvulling op deze vraag-aanbodconfrontatie kan bekeken worden hoe groot de discrepantie tussen vraag en aanbod zou zijn, als de vraag naar bio- en cognitieve psychologen in Nederland gelijk zou zijn aan die in de Verenigde Staten.

De tweede invalshoek voor de arbeidsmarktperspectieven van bio- en cognitieve psychologen betreft niet het verwachte aantal banen dat typisch voor bio- en cognitieve psychologie zal ontstaan, maar een vergelijking van de algemene arbeidsmarktperspectieven voor afgestudeerde bio- en cognitieve psychologen vergeleken met studenten uit vergelijkbare richtingen. Een indicatie van deze algemene perspectieven kan verkregen worden door de beroepsverdeling van de betreffende groep psychologen te relateren aan de arbeidsmarktindicatie en arbeidsmarktprognoses voor 1998 per beroepsklasse van het ROA. Deze prognoses en indicatoren betreffen de uitbreidings- en vervangingsvraag per beroep, de conjunctuurgevoeligheid van de werkgelegenheid, de sectorspreiding en een algehele typering van het werkgelegenheidperspectief per beroepsklasse ${ }^{16}$. De indicatoren van de conjunctuurgevoeligheid en de sectorspreiding van de werkgelegenheid kunnen daarbij geïnterpreteerd worden als algemene risico-indicatoren met betrekking tot de bestaande onzekerheid van de toekomstige arbeidsmarktsituatie op lange termijn. Om een beeld te kunnen krijgen van de belangrijkste beroepsterreinen van bio- en cognitieve psychologen over de beroepen moet gebruik gemaakt worden van de informatie uit het NIP-ledenbestand. Deze biedt echter voornamelijk informatie per bedrijfstak en niet per beroep. Voor een koppeling naar beroepen moet daarom verder nog gebruik gemaakt worden van de spreiding van sociale wetenschappers over de verschillende bedrijfs- en beroepsklassen. Een dergelijke combinatie van de gegevens over de specifieke groep bio- en cognitieve psychologen met de ROA-

16. Zie bijvoorbeeld ROA (1992a, 1992b). 
prognoses per beroep kan inzicht geven in de positie van bio- en cognitieve psychologen ten opzichte van andere psychologierichtingen en de sociale wetenschappen als geheel. Voor het bepalen van de groep studierichtingen die een vergelijkbare groep studenten als instroom hebben ontbreekt echter de benodigde data. Volstaan moet worden met de veronderstelling dat de instroom van bio- en cognitieve psychologie vergelijkbaar zal zijn met de instroom van sociale wetenschappen in het algemeen.

Bij het opstellen van de bovengenoemde prognoses zal veelvuldig een koppeling gemaakt moeten worden tussen diverse indelingen van afstudeerrichtingen en specialisaties binnen de psychologie bovendien dient een definitief onderscheid te worden gemaaktn tussen de aan bioen cognitieve psychologie verwante richtingen en de hieraan niet-verwante richtingen. Om deze koppeling, die van groot belang is voor de nauwkeurigheid van de resultaten, zo goed mogelijk tot stand te brengen, is hiervoor de inbreng van enkele vakinhoudelijke deskundigen vereist.

Verder kan overwogen worden om de prognoses, als deze zijn opgesteld, voor te leggen aan deskundige sleutelpersonen die op de hoogte zijn van bepaalde ontwikkelingen binnen de psychologie. Een vergelijkbare aanpak werd gevolgd door Heijke en Beekman (1990). Deskundigen kunnen een oordeel geven over de plausabiliteit van bepaalde voorspellingen, zodat de eindresultaten beter op hun waarschijnlijkheid beoordeeld kunnen worden. Hiervoor zal een groep deskundigen moeten worden samengesteld.

Naast de reeds genoemde beperkingen van het onderzoek, zal het ook niet mogelijk zijn voorspellingen te doen van de werkloosheid onder bio- en cognitieve psychologen. Het is niet zinvol om te veronderstellen dat een mogelijk overschot aan bio- en cognitieve psychologen automatisch zal leiden tot de werkloosheid van deze groep. Er dient derhalve een verband gezocht te worden tussen de arbeidsmarktpositie en het werkloosheidspercentage van psychologen. Er zijn echter geen betrouwbare bronnen met betekking tot het werkloosheidspercentage onder psychologen, zodat het niet zinvol is dergelijke prognoses op te stellen.

Concluderend kan gesteld worden dat, voornamelijk dankzij de beschikbaarheid van het NIPledenbestand, het mogelijk is verantwoorde richtinggevende prognoses op te stellen voor de arbeidsmarktsituatie van bio- en cognitieve psychologen tot 1998. Deze prognoses bestaan enerzijds uit een confrontie van vraag (vervangingsvraag en uitbreidingsvraag) en aanbod voor banen die typisch geschikt zijn voor studenten van de Maastrichtse psychologiestudie en anderzijds uit een indicatie, aan de hand van de ROA-werkgelegenheidstyperingen per beroep, van de algemene werkgelegenheidssituatie van de afgestudeerde bio- en cognitieve psychologen in vergelijking met studenten van andere richtingen. 


\section{LITERATUUR}

Beekman, Th.B.J. en J.A.M. Heijke (1990), De arbeidsmarktperspectieven voor klinisch psychologen tot 1995, ROA-R-1990/3, Maastricht.

Blaug, M. (1987), The Economics of Education and the Education of an Economist, Aldershot.

Bureau of Labor Statistics (1988), Occupational Projections and Training Data. Bulletin 2301, U.S. Department of Labor, Washington D.C.

Bureau of Labor Statistics (1984), Occupational Outlook Handbook, 1984-85 edition. US Department of Labor, Washington D.C.

CPB (1993), Centraal Economisch Plan 1993. Den Haag.

Commissie Psychologie (1993), Psychologie in Maastricht. Rijksuniversiteit Limburg.

Dekker, R.J.P., A. De Grip en P.J.E. van de Loo (1990), 'ROA-Beroepenclassificatie 1990', ROA-W-1990/9, Maastricht.

Dijkstra, C. en J. Bannenberg (1986), 'Er zijn teveel klinisch psychologen'. De Psycholoog 11-4, p. $178-182$.

Dijkstra, C. en Van der Donk (1988), De arbeidsmarkt van hoger opgeleiden per opleidingscategorie van 1978 tot 2000. HW/T-notitie, Ministerie van Onderwijs en Wetenschappen.

Eijs, P. van (1993), 'The Manpower Requirements Approach: Background and Methodology', ROA-RM-1993/3E.

Holtzer, F.H.J.M. (1984), 'Is er toekomst voor psychologen?' De Psycholoog 14-6, p 257-266.

Janssen, J., F. Derks en B. van Giels (1988), 'Apelles post Tabulam: Studenten en oudstudenten over hun opleiding'. Notitie Katholieke Universiteit Nijmegen.

Jonkergouw, Th.A.J.M. (1985a), 'Opleiden voor werk betekent werk maken van de opleiding. Een APA-historie (I)'. De Psycholoog 20-11, p. 526-529.

Jonkergouw, Th.A.J.M. (1985b), 'Opleiden voor werk betekent werk maken van de opleiding. Een APA-historie (II)'. De Psycholoog 20-12, p. 577-582.

Jonkergouw, Th.A.J.M. (1986), 'Opleiden voor werk betekent werk maken van de opleiding. Een APA-historie (III)'. De Psycholoog 21-4, p. 205-213.

Kerkhof, A.J.F.M. en G.I. Engels, (1986), 'Enkele gegevens over de werksituatie van psychologen afgestudeerd tussen september 1983 en september 1986 aan de Rijksuniversiteit Leiden, met als specialisatie klinische psychologie'. Interne notitie Rijksuniversiteit Leiden.

Kops en Swanborn (1993), 'Een opleiding voor de markt, of een markt voor de opleiding? Traditionele en recente typen van sociale wetenschappers op de arbeidsmarkt'. Universiteit Utrecht, verschijnt binnenkort.

Krijnen, G. (1975), Ontwikkeling functievervulling van psychologen, deel I. ITS, Nijmegen.

Krijnen, G. (1976), Ontwikkeling funktievervulling van psychologen, deel II, ITS, Nijmegen. 
Loo, P. van de, Ramaekers, Van der Velden (1992), De arbeidsmarkt van afgestudeerden bij het Hoger Beroepsonderwijs. Diverse rapportages, HBO-raad, Den Haag.

Meerum Terwogt-Kouwenhoven, K. (1990), Niet gewogen, toch te licht bevonden. Analyse van de rendementsproblematiek aan de universiteit. Proefschrift Universiteit van Amsterdam.

Mensen Th. en Van der Burgh (1989), DIA-onderzoek, Groningen.

Ministerie van Onderwijs en Wetenschappen (1990), Hoger onderwijs en onderzoek plan (HOOP), Feiten en cijfers. Zoetermeer.

Ministerie van Onderwijs en Wetenschappen (1992a), Referentieraming 1992. Twee delen, Zoetermeer.

Ministerie van Onderwijs en Wetenschappen (1992b), WO Verdeelraming 1992. Zoetermeer.

Ramaekers, G.W.M, en J.A.M. Heijke (1993), Arbeidsmarktscanner Rijksuniversiteit Limburg: Basismeting cohort '90. ROA-R-1993/1, Maastricht.

ROA (1992a), De Arbeidsmarkt naar opleiding en beroep tot 1994. ROA-R-1992/1A, Maastricht.

ROA (1992b), De arbeidsmarkt naar opleiding en beroep tot 1994. Statistische bijlage, Actualisering 1992, ROA-R-1992/8B, Maastricht.

Schaufeli, W.B. (1987), 'Werk en werkloosheid onder klinische psychologen'. Interne notitie RU Groningen.

Schaufeli, W.B. en A. de Vries (1987), 'Werk en werkloosheid onder klinisch psychologen'. De Psycholoog 13-7, p. .

Stapp, J., A.M. Tucker en G.R. vandenBos (1985), 'Census of Psychological Personnel: 1983'. American Psychologist, p. 1317-1351.

Webbink, H.D., U. de Jong, H. Oosterbeek en J. Roeteveld (1993), Verder Studeren Deel 2. Ministerie van Onderwijs en Wetenschappen, Zoetermeer.

Wieling, Van de Loo en Van der Velden (1993), Waar komen onze schoolverlaters terecht? De uitstroom en bestemming van het schooljaar 1990-1991. LDC, Leeuwarden.

Willems en De Grip (1993), Jeugd en Techniek. ROA-rapport, verschijnt binnenkort. 